[Vicino Oriente XXI (2017), pp. 225-256]

\title{
THE EL-ATAN TOMB: \\ AN EARLY BRONZE IVB FEMALE BURIAL IN THE HEART OF BETHLEHEM
}

Lorenzo Nigro - Daria Montanari - Sapienza University of Rome

Mohammed Ghayyada - Jehad Yasine - Ministry of Tourism and Antiquities of Palestine

An Early Bronze IVB tomb was discovered by the MOTA-DACH on June 2009 in the city of Bethlehem, nearby the Milk Grotto. Its architectural features, burials and associated funerary equipment are here considered and compared with those of other Early Bronze IV cemeteries and necropoleis of Southern Levant to grasp the historical-archaeological meaning of this discovery.

Keywords: Bethlehem; el-Atan; Early Bronze IV; necropolis; shaft-tomb

\section{INTRODUCTION}

This study stems from the project of rescue archaeology in the district of Bethlehem started in 2015, which is part of the cooperation agreement between Sapienza University of Rome and the Ministry of Tourism and Antiquities of Palestine - Department of Archaeology and Cultural Heritage concerning the protection of sites in the neighbourhood of Bethlehem. ${ }^{1}$ The Aim of this paper is to contextualize the el-Atan Tomb in a regional frame, and to appraise it within the funerary customs of Early Bronze IV central Palestine, also in the light of the recently discovered cemeteries of Khalet al-Jam'a and Jebel Dhaher at Bethlehem itself. ${ }^{2}$

\section{THE EL-ATAN TOMB}

On $18^{\text {th }}$ June 2009 a tomb was discovered during some construction works for a private house, $400 \mathrm{~m}$ east of the Nativity Church, along el-Atan street, in the city of Bethlehem (fig. 1). ${ }^{3}$ In the same day, the Ministry of Tourism and Antiquities (MOTA) and the Department of Antiquities and Cultural Heritage (DACH) of Bethlehem, directed by Mohammed Ghayyada, with the participation of the Palestinian Tourist Police, started rescue excavations. Works were carried out under pressure of ongoing building activities in a week. A summary of the discoveries is offered in this article.

\subsection{The tomb}

The tomb consisted of a large round burial chamber and one vertical shaft (fig. 2). The shaft was explored partially due to its location in a nearby land belonging to a different owner which had already built on it. The bulldozer opened accidentally an entrance on the eastern wall of the chamber, luckily without damaging neither human remains nor the associated funerary equipment (figs. 3-4). This allowed for the excavation of the chamber and for the description of its structure as follows. The tomb consisted if a rock-cut underground chamber (Chamber 1), oval-shaped, $4.9 \times 3.8 \mathrm{~m}$, with the main axis oriented north-south. The domed roof was $1.7 \mathrm{~m}$ high, hewn in the yellowish friable limestone

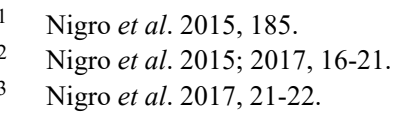

ISSN 0393-0300 
bedrock typical of the eastern slopes of the Nativity Church hill. The shaft and the entrance were to the north of the chamber, closed by a roughly carved limestone slab. On the tomb walls traces of hewing were visible (fig. 5), made by a $4 \mathrm{~cm}$-wide tool (adze?), ${ }^{4}$ especially on its western and southern sides. Two niches, circa $30 \mathrm{~cm}$ wide, were cut into the northern (Niche 1) and the western (Niche 2) walls of the cave, the former just aside the entrance.

Debris and soil collapsed from the roof, named filling F.1, covered the northern half of the chamber. Under this debris layer, there was a red-brownish silty layer (F.2) spread almost all over the tomb, probably originated by natural drainage and erosion. The first depositional layer was, thus, filling F.3, represented by a dark red sandy soil $17-20 \mathrm{~cm}$ thick, with Burial 1 in the middle and its funerary set all around it. Further goods had been displaced along the western wall of the chamber, including some piled-up pottery vessels. Over the flattened bedrock floor (Locus L.4), almost in the middle of the chamber, a complete adult female skeleton ${ }^{5}$ (Burial 1; fig. 6) laid, flexed on the right side, north-west oriented and facing west; nearby another fragmentary skull (Burial 2) was found, possibly a relic of an earlier use of the chamber.

\subsection{The funerary assemblage}

The funerary set (fig. 7) comprised 16 pottery vessels: 4 four-spouted lamps, 5 bowls, 4 jars, 2 amphoriskoi, and a beaker, belonging to types dating back to the Early Bronze IVB. Several items accompanied the dead, namely a copper pin, 5 carnelian beads and a flint scraper. ${ }^{6}$

Four-spouted lamps with flat base retrieved in the tomb belong to the wheel made type (figs. 8-11). They were manufactured with a fine fabric and fired at a high temperature (more than $800^{\circ}$ ), with thin walls, suggesting a later date in the Early Bronze IV. ${ }^{7}$ The high number of lamps might indicate that the tomb had hosted more burials before.

Five simple wide shallow bowls show slight carination and combed decoration below the rim (figs. 12-13); they belong to a type common in southern Palestine. ${ }^{8}$

Amphoriskoi exhibit a large base, rounded body and small handles (they were made from a lump of clay applied and then pierced with a stick; fig. 14).

Jars are of medium size and have a flat base and ovoid shaped body (figs. 15-16). The body was hand-coiled and inside not always smoothed, the neck is wheel made built separately, and then added to the body, as usual in EB IVB vessels. ${ }^{9}$ The decoration, on jars and amphoriskoi, was obtained with a comb, with 5, 6 or 7 teeth, on the shoulders. Incised lines sometimes overlap in order to produce a thicker band. Jar BL1246 presents also a diagonal row of comb indentations. Jar BL1237 (fig. 21) is characterized by a very fine fabric and shows high firing, with a deeply engraved horizontal and wavy combed

4 These traces are comparable to those from Jebel Qa'aqir (Dever 2014, 20-21, fig. 2:19) and Khirbet el-Karmil (Dever 1975, 20-21).

5 Human remains were studied by Dr. Mohammad Al-Zawahra of the Department of Antiquities and Cultural Heritage of Bethlehem.

6 Nigro et al. 2017, 21-22.

7 Nigro 1999, 39.

8 D'Andrea 2014, vol. 2, 193

9 D'Andrea 2012, 24. 
decoration. ${ }^{10}$ Its capacity is $992-1130$ cc. ${ }^{11}$ It has been classified as 'outsize cup" ${ }^{12}$ or 'small biconical jar' ${ }^{13}$ and has some possible parallels in a jar from Jericho ${ }^{14}$ and in two jars retrieved in Cave II of 'Araq en-Na'saneh (Wadi ed-Daliyeh). ${ }^{15}$

\subsubsection{Pottery catalogue}

BL1229, lamp (fig. 8). Context: Chamber 1, Filling 3. Class: Simple Ware (for special uses). State of preservation: complete. Technique of manufacture: hand and wheel made. Firing: medium-high. Outer colour: 2.5 YR 8/4 (pink); inner colour: 2.5 YR 8/4 (pink). Temper/inclusions: mineral and vegetal; dimension: small; frequency: medium. Rim diameter: $17 \mathrm{~cm}$; base diameter: $8 \mathrm{~cm}$; height: $4.5 \mathrm{~cm}$; rim width: $0.4 \mathrm{~cm}$; wall width: 0.8 $\mathrm{cm}$; base width: $0.5 \mathrm{~cm}$. Dating: EB IVB. Bibliography: Dever 2014, fig. 2.97:7

BL1230, lamp (fig. 9). Context: Chamber 1, Filling 3. Class: Simple Ware (for special uses). State of preservation: whole form, soot on one spout. Technique of manufacture: handmade. Firing: medium. Fabric colour: 2.5 YR 7/4 (light reddish brown); outer colour: 2.5 YR 7/4 (light reddish brown); inner colour: 2.5 YR 7/4 (light reddish brown). Temper/inclusions: mineral and vegetal; dimension: small and medium; frequency: medium. Rim diameter: $11 \mathrm{~cm}$; base diameter: $7 \mathrm{~cm}$; height: $4.7 \mathrm{~cm}$; rim width: $0.5 \mathrm{~cm}$; wall width: $0.5 \mathrm{~cm}$; base width: 0.6 cm. Dating: EB IVB. Bibliography: Dever 2014, fig. 2.90:1.

BL1231, lamp (fig. 10). Context: Chamber 1, Filling 3. Class: Simple Ware (for special uses). State of preservation: complete, soot on one spout. Technique of manufacture: hand and wheel made. Firing: high. Outer colour: 2.5 YR 7/6 (light red); inner colour: 2.5 YR 7/6 (light red). Temper/inclusions: mineral and vegetal; dimension: small; frequency: low. Rim diameter: $15.1 \mathrm{~cm}$; base diameter: $8 \mathrm{~cm}$; height: $4.5 \mathrm{~cm}$; rim width: 0.35 cm; wall width: $0.5 \mathrm{~cm}$; base width: $0.4 \mathrm{~cm}$. Dating: EB IVB. Bibliography: Gonen 2001, fig. 31:10.

BL1234, lamp (fig. 11). Context: Chamber 1, Filling 3. Class: Simple Ware (for special uses). State of preservation: complete, soot on two spouts. Technique of manufacture: hand and wheel made. Firing: mediumhigh. Outer colour: 5 YR 5/8 (yellowish red); inner colour: 5 YR 5/8 (yellowish red). Temper/inclusions: mineral and vegetal; dimension: small and medium; frequency: medium. Rim diameter: $15.8 \mathrm{~cm}$; base diameter: $8.5 \mathrm{~cm}$; height: $3.5 \mathrm{~cm}$; rim width: $0.4 \mathrm{~cm}$; wall width: $0.5 \mathrm{~cm}$; base width: $0.5 \mathrm{~cm}$. Dating: EB IVB. Bibliography: Smith 1962, pl. X:6-8; Dever 1975, fig. 4:16; Gonen 2001, fig. 21:6.

BL1244, beaker (fig. 12). Context: Chamber 1, Filling 3. Class: Simple Ware. State of preservation: complete. Technique of manufacture: hand and wheel made. Firing: low. Outer colour: 2.5 YR 7/8 (light red); inner colour: 2.5 YR 7/8 (light red). Temper/inclusions: mineral; dimension: small; frequency: medium. Rim diameter: $8.5 \mathrm{~cm}$; base diameter: $5 \mathrm{~cm}$; height: $9.5 \mathrm{~cm}$; rim width: $0.3 \mathrm{~cm}$; wall width: $0.5 \mathrm{~cm}$; base width: $0.5 \mathrm{~cm}$. Dating: EB IVB Bibliography: Prag 1995, fig. 23:11; Gonen 2001, fig. 19:4.

BL1228, bowl (fig. 13). Context: Chamber 1, Filling 3. Class: Simple Ware. State of preservation: complete. Technique of manufacture: hand and wheel made. Firing: high. Outer colour: 7.5 YR 8/4 (pink); inner colour: 7.5 YR 8/4 (pink). Temper/inclusions: mineral and vegetal; dimension: small; frequency: medium. Decoration: combed. Rim diameter: $17.8 \mathrm{~cm}$; base diameter: $10.5 \mathrm{~cm}$; height: $6.4 \mathrm{~cm}$; rim width: $0.4 \mathrm{~cm}$; wall width: $0.7 \mathrm{~cm}$; base width: $0.4 \mathrm{~cm}$. Dating: EB IVB. Bibliography: Dever 2014, fig. 2.96:10.

BL1232, bowl (fig. 13). Context: Chamber 1, Filling 3. Class: Simple Ware. State of preservation: complete. Technique of manufacture: hand and wheel made. Firing: medium-high. Fabric colour: 7.5 YR 6/8 (reddish yellow); outer colour: 7.5 YR 8/4 (pink); inner colour: 7.5 YR 8/4 (pink). Temper/inclusions: mineral; dimension: small; frequency: medium-high. Decoration: combed. Rim diameter: $20.8 \mathrm{~cm}$; base diameter: $11.5 \mathrm{~cm}$; height: 7.3 $\mathrm{cm}$; rim width: $0.5 \mathrm{~cm}$; wall width: $0.5 \mathrm{~cm}$; base width: $0.5 \mathrm{~cm}$. Dating: EB IVB. Bibliography: Tufnell 1958, pl. 66:430; Dever 2014, fig. 2.89:12.

BL1233, bowl (fig. 13). Context: Chamber 1, Filling 3. Class: Simple Ware. State of preservation: complete. Technique of manufacture: hand and wheel made. Firing: medium. Outer colour: 7.5 YR 6/6 (reddish brown)

10 D'Andrea 2014 vol. 1, 102, fig. 3.62.

11 Shaub - Rast 1989, 493-494, fig. 285.

12 Dever 1974, 38, pls. 12:6, 13:3.

13 Nigro 2003a, fig. 20:5.

14 Kenyon - Holland 1982, fig. 94:10.

15 Dever 1974, 38, pls. 12:6, 13:3. These two can be compared especially for combed decoration and S-shaped profile, but not for the rim, pointed in the el-Atan specimen and flattened in the other two. 
inner colour: 7.5 YR 6/6 (reddish brown). Temper/inclusions: mineral and vegetal; dimension: small; frequency: medium. Rim diameter: $17.7 \mathrm{~cm}$; base diameter: $10.7 \mathrm{~cm}$; height: $6 \mathrm{~cm}$; rim width: $0.3 \mathrm{~cm}$; wall width: $0.6 \mathrm{~cm}$; base width: $0.4 \mathrm{~cm}$. Dating: EB IVB. Bibliography: Dever 2014, fig. 2.91:10.

BL1235, bowl (fig. 12). Context: Chamber 1, Filling 3. Class: Simple Ware. State of preservation: complete. Technique of manufacture: hand and wheel made. Firing: high. Outer colour: 7.5 YR 7/4 (pink); inner colour: 7.5 YR 7/4 (pink). Temper/inclusions: mineral and vegetal; dimension: small; frequency: medium. Rim diameter: 15.8 cm; base diameter: $8 \mathrm{~cm}$; height: $6.4 \mathrm{~cm}$; rim width: $0.3 \mathrm{~cm}$; wall width: $0.7 \mathrm{~cm}$; base width: $0.5 \mathrm{~cm}$. Dating: EB IVB. Bibliography: Dever 2014, fig. 2.97:8.

BL1236, bowl (fig. 13). Context: Chamber 1, Filling 3. Class: Simple Ware. State of preservation: complete. Technique of manufacture: hand and wheel made. Firing: medium-high. Outer colour: 7.5 YR 8/3 (pink); inner colour: 7.5 YR 8/3 (pink). Temper/inclusions: mineral and vegetal; dimension: small and medium; frequency: medium. Rim diameter: $26.7 \mathrm{~cm}$; base diameter: $9.5 \mathrm{~cm}$; height: $10 \mathrm{~cm}$; rim width: $0.5 \mathrm{~cm}$; wall width: $0.6 \mathrm{~cm}$; base width: $0.8 \mathrm{~cm}$. Dating: EB IVB. Bibliography: Dever 2014, fig. 5.10:4.

BL1227, amphoriskos (fig. 14). Context: Chamber 1, Filling 3. Class: Simple Ware. State of preservation: complete. Technique of manufacture: hand and wheel made. Firing: medium. Fabric colour: 5 YR 7/6 (reddish yellow); outer colour: 5 YR 7/6 (reddish yellow); inner colour: 5 YR 7/6 (reddish yellow). Temper/inclusions: mineral; dimension: small; frequency: high. Decoration: combed. Rim diameter: $8.3 \mathrm{~cm}$; base diameter: $8 \mathrm{~cm}$; height: $15.5 \mathrm{~cm}$; rim width: $0.4 \mathrm{~cm}$; wall width: $0.4 \mathrm{~cm}$; base width: $0.5 \mathrm{~cm}$. Dating: EB IVB. Bibliography: Dever 2014, fig. 2.88:5.

BL1245, amphoriskos (fig. 14). Context: Chamber 1, Filling 3. Class: Simple Ware. State of preservation: whole form. Technique of manufacture: handmade. Firing: medium-high. Fabric colour: 10 YR 7/6 (yellow); outer colour: 10 YR 7/6 (yellow); inner colour: 10 YR 7/6 (yellow). Temper/inclusions: mineral; dimension: small and medium; frequency: medium-high. Decoration: combed. It was made after the application of handles, as it also at Efrata. ${ }^{16}$ Rim diameter: $10 \mathrm{~cm}$; base diameter: $7 \mathrm{~cm}$; height: $15 \mathrm{~cm}$; rim width: $0.3 \mathrm{~cm}$; wall width: $0.4 \mathrm{~cm}$; base width: $0.5 \mathrm{~cm}$. Dating: EB IVB. Bibliography: Dever 2014, fig. 2.89:7.

BL1246, jar (fig. 15). Context: Chamber 1, Filling 3. Class: Simple Ware. State of preservation: whole form. Technique of manufacture: hand and wheel made. Firing: medium-high. Fabric colour: 2.5 YR 7/6 (light red); outer colour: 2.5 YR 7/6 (light red); inner colour: 2.5 YR 7/6 (light red). Temper/inclusions: mineral and vegetal; dimension: small and medium; frequency: medium. Decoration: incised and combed. Rim diameter: $11 \mathrm{~cm}$; base diameter: $13 \mathrm{~cm}$; height: $24.5 \mathrm{~cm}$; rim width: $0.4 \mathrm{~cm}$; wall width: $0.6 \mathrm{~cm}$; base width: $0.5 \mathrm{~cm}$. Dating: EB IVB. Bibliography: Sa'ad 1964, pl. XXXV:1; Gonen 2001, fig. 21:1.

BL1237, jar (fig. 16). Context: Chamber 1, Filling 3. Class: Simple Ware. State of preservation: complete. Technique of manufacture: hand and wheel made. Firing: medium-high. Fabric colour: 2.5 YR 6/6 (light red); outer colour: 7.5 YR 7/2 (pinkish gray); inner colour: 7.5 YR 7/2 (pinkish gray). Temper/inclusions: mineral and vegetal; dimension: small; frequency: low. Decoration: combed. Rim diameter: $14.7 \mathrm{~cm}$; base diameter: $13.5 \mathrm{~cm}$; height: $19 \mathrm{~cm}$; rim width: $0.4 \mathrm{~cm}$; wall width: $0.9 \mathrm{~cm}$. Dating: EB IVB. Bibliography: Kenyon - Holland 1982, fig. 94:10; Dever 1974, 38, pls. 12:6, 13:3; Aharonovich 2016, fig. 11:2.

\subsubsection{Personal items catalogue (fig. 17)}

BL1238, copper pin. Context: Chamber 1, Filling 3. State of preservation: complete. Material: copper. Technique of manufacture: moulded. Length: $12 \mathrm{~cm}$; width: $0.6 \mathrm{~cm}$ (head); diameter: $0.2 \mathrm{~cm}$; weight: $3 \mathrm{~g}$. Description: copper pin with rolled head and circular cross section belonging to a well-known type. ${ }^{17}$ Dating: EB IVB. Bibliography: Lapp 1966, fig. 2:8.

BL1226, flint scraper. Context: Chamber 1, Filling 3. State of preservation: complete. Material: flint. Technique of manufacture: chipped. Fabric colour: 5 YR 4/6 (yellowish red). Length: $4.2 \mathrm{~cm}$; width: $2 \mathrm{~cm}$; thickness: $\max 0.8 \mathrm{~min} 0.2 \mathrm{~cm}$. Description: flint scraper with trapezoid cross section, cortex on the tang, retouched along the blade. Dating: EB IVB. Bibliography: Ellis 2010, 255, fig.13.1:1.

BL1225, bead. Context: Chamber 1, Filling 3. State of preservation: complete. Material: carnelian. Technique of manufacture: smoothed, pierced. Fabric colour: 5 YR 7/8 (reddish yellow). Thickness: $0.3 \mathrm{~cm}$; diameter: 0.8 cm. Description: donut shaped carnelian bead. Dating: EB IVB. Bibliography: Kenyon 1965, figs. 25:2; 33:5.

16 Gonen 2001, 31.

17 Gernez 2008, 247-248, type Ep.1, fig. 8, pl. 11. 
BL1239, bead. Context: Chamber 1, Filling 3. State of preservation: complete. Material: carnelian. Technique of manufacture: smoothed, pierced. Fabric colour: 2 YR 7/8 (light red). Thickness: $0.2 \mathrm{~cm}$; diameter: $0.6 \mathrm{~cm}$. Description: donut shaped carnelian bead. Dating: EB IVB. Bibliography: Kenyon 1965, figs. 25:2; 33:5.

BL1240, bead. Context: Chamber 1, Filling 3. State of preservation: complete. Material: carnelian. Technique of manufacture: smoothed, pierced. Fabric colour: 5 YR 7/8 (reddish yellow). Thickness: $0.3 \mathrm{~cm}$; diameter: 0.9 cm. Description: donut shaped carnelian bead. Dating: EB IVB. Bibliography: Kenyon 1965, fig. 25:1.

BL1241, bead. Context: Chamber 1, Filling 3. State of preservation: complete. Material: carnelian. Technique of manufacture: smoothed, pierced. Fabric colour: 5 YR 7/8 (reddish yellow). Thickness: $0.2 \mathrm{~cm}$; diameter: 0.7 cm. Description: donut shaped carnelian bead. Dating: EB IVB. Bibliography: Kenyon 1965, figs. 25:2; 33:5.

BL1242, bead. Context: Chamber 1, Filling 3. State of preservation: complete. Material: carnelian. Technique of manufacture: smoothed, pierced. Fabric colour: 2.5 YR 7/8 (light red). Thickness: $0.2 \mathrm{~cm}$; diameter: $0.7 \mathrm{~cm}$. Description: donut shaped carnelian bead. Dating: EB IVB. Bibliography: Kenyon 1965, figs. 25:2; 33:5.

\section{EARLY BRONZE IV CEMETERIES IN THE AREA OF BETHLEHEM}

The district of Bethlehem and especially the rocky flanks of the mountains of the Judean Deserts hosted several cemeteries during the Early Bronze IV/Intermediate Bronze Age, possibly referring to tribes of semi-nomadic shepherds living in the radiant valleys descending down to the Dead Sea from the central highlands. ${ }^{18}$

Numerous attestations are indicative of the presence of Early Bronze IV cemeteries in the area of Bethlehem, on rocky plateaux and hills all around the town. ${ }^{19}$

A group of tombs was excavated in the easternmost fringe of the Beit Sahur hill in $1908-1909,{ }^{20}$ on the slopes of the nearby "Shepherds' Field", and some pottery vessels, said to come from these tombs, are nowadays preserved in the St. Mary's Dormition Museum in Jerusalem. ${ }^{21}$ EB IV tombs in the area of Bethlehem are reported as the sources of a group of vessels in the Herbert E. Clark Collection of ancient pottery presently in the YMCA of Jerusalem, recovered in 1912 and published by G.E. Wright. ${ }^{22}$

An Early Bronze IV amphoriskos said from Battir (fig. 18), acquired in 1957, is in the Museum of the Flagellation Monastery at Jerusalem. It has a flat base, round body and a decoration on the shoulders composed by an upper line of diagonal grooved incision (as a comb stamping) and a combed band. ${ }^{23}$ Moreover, in the Flagellation Museum there is an Early Bronze IV jar (fig. 19), with combed decoration on the shoulder, ovoid body and flat base, found in Bethlehem and brought to the same museum in $1957 .{ }^{24}$ Both vessels might come from the cemetery of Beit Sahur.

To these sparse data it is now possible to add new records from the recently discovered cemeteries of Khalet al-Jam'a ${ }^{25}$ and Jebel Dhaher, ${ }^{26}$ both located within a radius of $2.5 \mathrm{~km}$ south of Bethlehem.

\footnotetext{
Nigro 2003a, 138-139; D’Andrea 2014 vol. 1, 231

Nigro 2015, 5.

Hänsler 1908; 1909; Vincent 1909, 116-117.

Saller 1962, 160-162.

Wright 1938, figs. 1:1-4, 2:1-4; Bagatti 1952, 265-267.

Saller 1962, 166, figs. $1: 10 ; 3: 3$

Saller 1962, 162-163, fig. 2:16.

Nigro et al. 2015.

6 Nigro et al. 2017.
} 
The shaft-tombs necropolis of Khalet al-Jam'a was in use since the Early Bronze IV, throughout the Middle Bronze until the Iron Age. In Tomb C12 of the Early Bronze IV a single primary deposition is documented. ${ }^{27}$

The shaft-tombs of the necropolis of Jebel Dhaher were also first excavated during the Early Bronze IV and remained in use during the Middle Bronze and, some of them, also in the Iron Age.

The el-Atan Tomb, being included within the elongated burial area surrounding to the east and to the south of the Nativity Church, ${ }^{28}$ might, nonetheless, represent a north-western ramification of the Beit Sahur cemetery.

\section{BETHLEHEM IN THE FRAME OF THE EARLy BRONZE IV CEMETERIES OF THE CENTRAL HiLls AND JUDEAN HiLls OF PALESTINE}

Due to the fragmented knowledge and the lack of a clear profile of Bethlehem's history in the Bronze Age IV/Intermediate Bronze Age, it is perhaps useful to observe the regional scenario in an area circa $30 \mathrm{~km}$ to the north, up to Dhahr Mirzabaneh in the Central Hills, and to the south, down to Khirbet el-Karmil in the Judean Hills (fig. 20). ${ }^{29}$

A northern cluster of cemeteries has been identified in the area between Dhahr Mirzbaneh $^{30}$ and 'Ain Samiya. ${ }^{31}$ At this site D.G. Lyon recognized in 1906-1907 more than one-hundred plundered tombs, dating from the Early Bronze IV until the Middle Bronze II. They had round shafts with one or more circular or oval chambers with domed roof. Funerary sets were composed by pottery vessels, like four-spouted lamps, bowls, ovoid jars, bottles, teapots, as well as pins, dagger, javelins, and personal items. The necropolis of Dhahr Mirzbaneh was excavated in the sixties of the twentieth century by P.W. Lapp, who uncovered more than 150 graves. ${ }^{32}$ It was a necropolis with single- or multi-chambered shaft tombs. Shaft were round and usually show a step at their bottom introducing into the underground chamber, a feature also occurring at el-Jib, Jebel Dhaher, and Khirbet elKarmil. ${ }^{33}$ Chambers were domed and circular in plan, sealed by large blocking stones. ${ }^{34}$ As it concerns human remains, none of the burials seems to be a primary articulated deposition; they usually are single, but some multiple-burials are also attested. ${ }^{35}$ Funerary sets include medium and small jars, amphoriskoi, cooking pots, bowls and cups. Dating features can be distinguished in small jars with flat base, rounded handmade body and attached wheel made neck: the decoration is represented by incised, combed and finger-

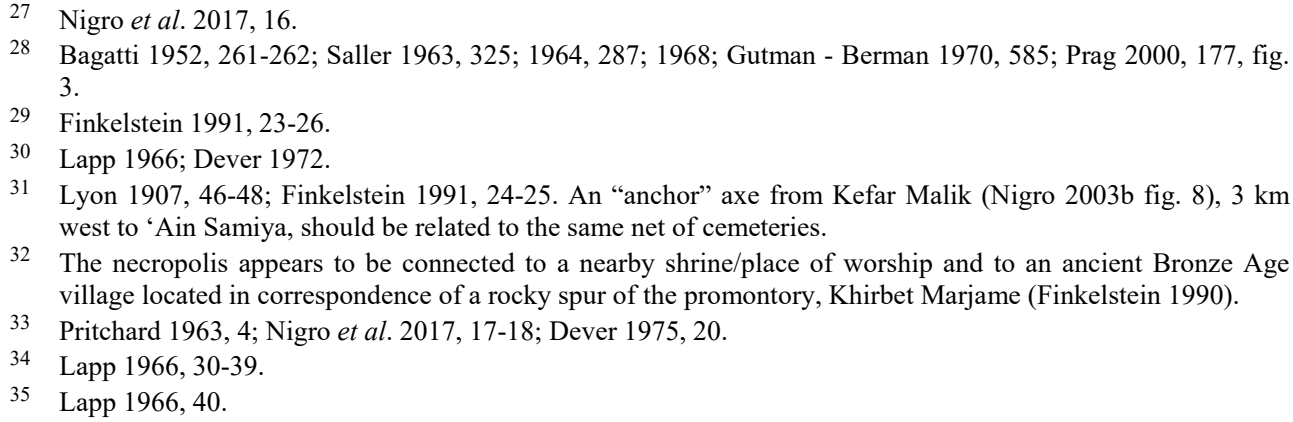

32 The necropolis appears to be connected to a nearby shrine/place of worship and to an ancient Bronze Age village located in correspondence of a rocky spur of the promontory, Khirbet Marjame (Finkelstein 1990). 
moulded elements, as it is typical of Early Bronze Age IVB.$^{36}$ The pottery collected in these cemeteries have been ascribed to the 'Central Hill Family,.

The tomb types established by K.M. Kenyon ${ }^{38}$ after the study of the Jericho necropolis ${ }^{39}$ one of the largest of the whole Levant,${ }^{40}$ may be also used to classify the elAtan Tomb, which falls into the so-called "Dagger Type", although it hosted a female primary deposition. ${ }^{41}$

Some parallelisms can be established also with the shaft-tombs cemetery of el-Jib. ${ }^{42}$ Here tombs had round shaft and one round or elliptical chamber and a funerary equipment represented by a limited ceramic repertoire, small and medium globular jars, often with combed decoration, four-spouted lamps, and weapons.

Moreover, a pattern of burials on hill slopes around the boundaries of Jerusalem can provide convincing comparisons to the el-Atan Tomb. A cemetery on the Mount of Olives was discovered and excavated by K.M. Kenyon during the $1965 .{ }^{43}$ Eleven tombs in three areas, Area A, B, and C, were identified. ${ }^{44}$ They were rock-cut tombs with round shaft and roughly round chamber, showing architectural features similar to those of Jericho's "Dagger Type", but quite larger, like the tomb of el-Atan. ${ }^{45}$

Another possible comparison is the tomb discovered in the village of Silwan (Hablat alAmud), in September $1941 .{ }^{46}$ This tomb had square shaft and two chambers. The funerary equipment was composed by seventeen Early Bronze IV vessels, as medium jars, bottles and four-spouted lamps, four plain pins, some rivets, and numerous beads made of different semiprecious material, including carnelian. ${ }^{47}$ The neighbourhood of Jerusalem was populated by EB IV cemeteries ${ }^{48}$ used by semi-nomadic tribes, a scenario parallel or similar to that reconstructed in the area of Bethlehem (fig. 1). ${ }^{49}$

36 Furthermore, also material from Sinjil (Dever 1971) should be add to try to propose a more complete reading of the funerary equipment related to that net of cemeteries.

37 Dever 1972, 109-110. According to D'Andrea (2014 vol. 1, 38, 125-126, 201-206; vol. 2, 91-95) this pottery horizon can be ascribed to the ceramic province of South-central Palestine (with previous literature)

38 Tomb types were distinguished on the basis of location, shape of the rock-cut chamber and shaft, burial custom and funerary assemblage (Kenyon 1960, 180-185; 1965, 33-38).

39 Nigro 2003a, 134-138.

40 J. Garstang discovered it during the first British Expedition of the Thirties (Garstang 1932; 1934; 1936).

41 E.g. Tomb A105 shows the same skeletal displacement of el-Atan (Kenyon 1960, 197; Palumbo 1986, 292) The presence of female burials within the "Dagger Group", characterized by the presence of copper pins has been already pointed out (Palumbo 1987; Nigro 2003a, 135).

42 Pritchard 1963. Some other Early Bronze IV shaft-tombs were found at Giv'at Ze'ev, north-west of el-Jib, in 1990 (Dadon 1997; The West Bank and East Jerusalem Searchable Map http://digitallibrary.usc.edu/cdm/map/collection/p15799coll74)

43 Kenyon 1966

44 Prag 1995. Some EB IV vessels found by Captain Charles Warren in 1867 possibly derive from the same cemetery (Wilson - Warren 1871, 306, 475-477). Another four spouted lamp was found in the vicinity by $\mathrm{H}$. Vincent (Vincent 1914, fig. 9:e).

45 Funerary assemblages of these tombs, however, are characterized by pottery, including bottles and fourspouted lamps; no weapons, beads or personal ornaments are present (Prag 1995, 234-235).

46 Sa'ad 1964

47 Sa'ad 1964; Rahmani 1981, 230

48 An Early Bronze IV shaft-tomb cemetery was uncovered north of Jerusalem, at Geva Binyamin (Aharonovich 2016), and at Ras Abu Ma'aruf/Pisgat Ze'ev (Seligman 1993, 52; 1995). This cemetery exhibits similar 
South of Bethlehem and between it and Hebron, other two cemeteries may belong to groups connected with those using the cemeteries of Jebel Daher and Khalet al-Jam'a: Efrata and Kirbet Kufin. The necropolis of Efrata is extended on the southern slope of a hill over an area of 0.2 hectares. Tombs have round or square shafts, and one or more chambers. ${ }^{50}$ In all of the seven intact caves dating from Early Bronze IV, burials were secondary and disarticulated, as it was also in the case of Silwan, Dhahr Mirbaneh and Jebel Qa'aqir. The pottery repertoire was limited and included jars, amphoriskoi, carinated bowls, cups, and lamps, but teapots are missing, as in the case of el-Atan. ${ }^{51}$

It is worth recalling the site of Tequ'a, south-east of Bethlehem. A group of vessels dating back to the Early Bronze IV is kept in the collection of the Museum of Flagellation in Jerusalem. They are said to come from the neighbourhood of Tequ'a. ${ }^{52}$ A recent survey has in facts shown that a cemetery of round shaft tombs did exist also on this prominent mound, ${ }^{53}$ and it seems quite probable that material in the Flagellation Museum came from this cemetery.

The western slope of the Khirbet Kufin was occupied by a necropolis of shaft-tombs dating back to from the beginning of the Early Bronze Age to the Middle Bronze II, terraced with orchards at the moment of discovery in 1962. Combed globular jars of Tomb 2 and of Lower Stratum of Chambers 3-4, in Tomb 3 of Khirbet Kufin, ${ }^{54}$ present general features similar to two jars of the el-Atan Tomb.

Three cemeteries dated to the Early Bronze IV were identified in the site of Jebel Qa'aqir, under the direction of W.G. Dever between 1967-1971. ${ }^{55}$ They were characterized by shaft-tombs with round shaft and one circular, sometimes irregular, single chamber, just occasionally double chamber. The roofing was frequently domed and some tombs had a decorative incision around the doorway. Several tombs had a lamp niche in the walls near the entrance, like Niche 1 in the el-Atan Tomb. ${ }^{56}$ Burials were secondary and disarticulated, and the funerary set was limited to ovoid jars, small amphoriskoi, both often with band

features to those observed at Nahal Ref'aim (Eisenberg 1993; Edelstein - Milevski 1994; Weksler-Bdolah 2017, 19-22), and Giv'at Massuah (Edelstein - Eisenberg 1984, 51-52). Near site of Manahat two different cemeteries were identified (Negbi 1964; Zehavi 1993, 67; Edelstein - Milevski - Aurant 1998). These are adjoining the site of er-Ras, where an Early Bronze IV necropolis was discovered (Hänsler 1909, 33-36; Saller 1962, 160). Moreover, a shaft-tomb cemetery was uncovered east of Jerusalem, during the construction of the Holyland Compound (Ben-Arieh 2000; Zelinger - Golan 2005; Milevski - Ben Or 2007; Milevski - Greenhut Agha 2010; Prag 2013, 105; Eirikh-Rose 2016). A group of Early Bronze IV vessels found in the site of 'Ain Karim, west of Jerusalem, now in the YMCA (two medium jars with combed decoration; Wright 1938, 29, fig. 1:5-6) and in the Flagellation Museum (an amphoriskos with combed decoration; Saller 1962, 166, fig. 1:9) should be mentioned. At Motza, near 'Ain Karim, an Early Bronze IV shaft-tomb was excavated by Bahat (1975).

49 Prag 2013, 105

50 Gonen 2001, 17-19.

1 Gonen 2001, 30-33.

52 Saller 1962, 164-165.

53 Lapp 1963, 124; 1966, 67; Saller 1964, 288; Nigro et al. 2017, 22.

54 Smith 1962, 9, 14, pls. X-XI, especially pls. X:1-2, 4-5; XI:2.

55 Dever 2014, 9-65.

56 Nigro 1999, 34 
combed decoration, bowls, cups, and four-spouted lamps, seldom copper daggers, javelins, and pins. ${ }^{57}$

The southernmost site taken into account in this article is Khirbet el-Karmil. Here one of the largest Palestinian necropolis of the Early Bronze Age was identified at the end of Sixties, displaced on five different areas, unfortunately heavily looted. ${ }^{58}$ Shaft-tombs were in use during the Early Bronze IV, only occasionally reused during the Middle Bronze Age, and had both single round chamber or double chamber; round shafts were widespread, even if square shapes were distinguished just in one area. Chambers had low domed roof and often lamp niches. The repertoire is represented by four spouted lamps, cups, bowls, ovoid jars, amphoriskoi, teapots, and pitchers, often decorated with a peculiar concentric incision or combing. Funerary sets were sometimes completed by copper daggers and javelins.

A seemingly recurrent feature in the Central Hills (Dhahr Mirzabaneh, 'Ain Samyia, and Sinjil), the neighbourhood of Jerusalem, and Judean Hills (the Bethlehem region) is the displacement of cemeteries in clusters, grouped e.g. on both sides flanks of wadis flowing towards the Jordan Valley, suggesting the use of nearby sites by tribes living and moving up and down the wadis. These clusters are often not clearly connected with a settlement, except for the case of Jericho, and seem to fit a pastoralist spatial organization and way of life.

\section{FINAL REMARKS}

The Bethlehemite tomb uncovered at el-Atan exhibits architectural features common to Early Bronze IV tombs known from several cemeteries, especially those of the Mount of Olives for shape and dimensions, and to those of Jebel Qa'aqir and Khirbet el-Karmil for the hewing technique of the underground chamber.

As regards the treatment of dead, and their funerary sets, Burial 1 of el-Atan, differently from what happens in numerous tombs at Dhahr Mirbaneh, Silwan, Efrata, and Jebel Qa'aqir, is a female primary deposition in crouched position, similar to some burials of the "Dagger Type" at Jericho. Such a treatment for a female individual is barely attested, and may suggest to re-appraise several burials from the above mentioned cemeteries, with special focus on the gender of the inhumations. ${ }^{59}$

As it concerns the pottery repertoire, that of the el-Atan Tomb follows the same composition of other Early Bronze IVB shaft-tombs, with a somewhat limited typological variety. The presence of given vessel types with their specific ceramological features ( $\S \S$ 2.2.-2.2.1.; lamps, bowls with slight carination, amphoriskoi, and small jars) as well as the absence of other shapes (teapot) point to a date late in the EB IVB and place the tomb's pottery repertoire within the southern tradition (presence of shallow carinated bowls, lack of squat jars, bottles, and teapots). ${ }^{60}$

Dever 1993, 665-666.

Dever 1975.

9 Palumbo 1986, 300

60 D'Andrea 2014 vol. 1, 201. 
In conclusion, the funerary custom and tomb equipment (with special reference to the wheel fashioned pottery), fit well the el-Atan Tomb into the central-southern pattern of Palestinian Early Bronze IVB. ${ }^{61}$

The presence of a copper pin and five carnelian beads highlight the female gender of the inhumation (Burial 1).

As regards the connection of the el-Atan Tomb to a cemetery, as it is commonly attested for such tombs, it seems reasonable to relate it to the nearby necropolis of Beit Sahur, located about $1.6 \mathrm{~km}$ east of it.

In conclusion, in spite of its partial destruction, the el-Atan Tomb adds one more tessera to the variegated mosaic of $3^{\text {rd }}$ millennium $\mathrm{BC}$ Bethlehem ${ }^{62}$, especially illustrating the funerary custom of the semi-nomadic tribes living in the area during the Early Bronze IV.

\section{REFERENCES}

AHARONOVICH, Y.

2016 Geva Binyamin (Adam): An Intermediate Bronze Age Cemetery and An Umayyad Farmhouse: Judea and Samaria Research Studies 25/1 (2016), pp. 9*-30*.

BAGATTI, B. O.F.M.

1952 Gli antichi edifici sacri di Betlemme in seguito agli scavi e restauri praticati dalla Custodia di Terra Santa (1948-51) (Studium Biblicum Franciscanum Collectio Maior 9), Gerusalemme 1952.

BAHAT, D.

1975 A Middle Bronze I Tomb Cave at Motza: Eretz Israel 12 (1975), pp. 18*-23*.

BEN-ARIEH, S.

2000 Salvage Excavations near the Holyland Hotel, Jerusalem: 'Atiqot 40 (2000), pp. 1-24.

DADON, M.

1997 A Burial Cave of the Middle Bronze Age I at Giv'at Ze'ev: 'Atiqot 32 (1997), p. 195.

D'ANDREA, M.

2012 The Early Bronze IV Period in South-Central Transjordan: Reconsidering Chronology Through Ceramic Technology: Levant 41 (2012), pp. 17-50.

2014 The Southern Levant in Early Bronze IV. Issues and perspectives in the pottery evidence DEVER, W.G. (Contributi e Materiali di Archeologia Orientale XVII), Roma 2014.

1971 An MBI Tomb Group from Sinjil: Bulletin of the American School of Oriental Research 204 (1971), pp. 31-37.

1972 Middle Bronze Age I Cemetery at Mirzbaneh and 'Ain Samiya: Israel Exploration Journal 22 (1972), pp. 95-112.

1974 The Middle Bronze Occupation and Pottery of 'Arâq en-Na'sâneh (Cave II): P.W. LAPP N.L. LAPP (eds.), Discoveries in the Wâdi ed-Dâliyeh (Annual of the American School of Oriental Research 41), Cambridge (MA) 1974, pp. 33-48.

1975 A Middle Bronze I Cemetery at Khirbet el-Kirmil: Eretz Israel 12 (1975), 18-33.

1993 Jebel Qa'aqir: E. STERN (ed.), The New Encyclopedia of Archaeological Excavations in the Holy Land, Vol. 2, Jerusalem 1993, pp. 665-667.

61 Greenhut 1995.

62 Nigro 2015, 4-5. 
2014 Excavations at the Early Bronze IV Sites of Jebel Qa'qair and Be'er Resisim (Studies in the Archaeology and History of the Levant 6), Winona Lake 2014.

EdElstein, G. - EISENBERG, E.

1984 'Emeq Refa'im: Exploration and Survey in Israel 3 (1984), pp. 51-52.

EDELSTEIN, G. - MiLEVSKI, I.

1994 The rural settlement of Jerusalem re-evaluated: Surveys and Excavations in the Repha'aim Valley and Mevasseret Yerushalayim: Palestine Exploration Quarterly 126 (1994), pp. 2-23.

Edelstein, G. - MiLEVSKi, I. - AuRAnt, S.

1998 The Rephaim Valley Project. Villages, Terraces, and Stone Mounds. Excavations at Manahat, Jerusalem, 1987-1989 (Israel Antiquity Authority Reports 3), Jerusalem 1998.

EIRIKH-Rose, A.

2016 Jerusalem, Holy Land Park: Hadashot Arkheologiyot 128 (2016) (www.hadashotEISENBERG, E. esi.org.il/report_detail_eng.aspx?id=24989\&mag_id=124)

1993 Jerusalem, Nahal Ref'aim - 1990: Exploration and Survey in Israel 12 (1993), pp. 67-71.

ELLIS, S.

2010 Ground Stones and Small Artifacts from the Cemeteries: S. RichARD - C.J. LONG JR. - P.S. Holdorf - G. Peterman (eds.), Khirbat Iskandar. Final Report on the Early Bronze IV. Area C "Gateway" and Cemeteries (Archaeological Expedition to Khirbat Iskandar and its Environs, Jordan 1; American Schools of Oriental Research Archaeological Reports 14), Boston 2010, pp. 251-260.

FINKELSTEIN, I.

1990 Archaeological Soundings at Dhahr Mirzabneh: Eretz Israel 21 (1990), pp. 239*-248*

1991 The Central Hill Country in the Intermediate Bronze Age: Israel Exploration Journal 41 (1991), pp. 19-45.

GARSTANG, J.

1932 City and Necropolis: Liverpool Annals of Archaeology and Anthropology XIX (1932), pp. 35-54.

1934 City and Necropolis (Fourth Report): Liverpool Annals of Archaeology and Anthropology XXI (1934), pp. 99-136.

1936 City and Necropolis (Fifth Report). VII. General Report for 1935: Liverpool Annals of GERNEZ, G. Archaeology and Anthropology XXII (1936), pp. 145-168.

2008 Le métal de Tell Arqa a l'âge du Bronze: Bulletin d'Archéologie et d'Architecture Libanaises 12 (2008), pp. 221-264.

GONEN, Y.

2001 Excavation at Efrata. A Burial Ground from the Intermediate and Middle Bronze Ages (Israel Antiquities Authority Reports 12), Jerusalem 2001.

GREENHUT, Z

1995 EB IV Tombs and Burials in Palestine: Tel Aviv 22 (1995), pp. 3-46.

GUTMAN, S. - BERMAN, A.

1970 Bethléem: Revue Biblique 77 (1970), pp. 583-585.

HÄNSLER, P.

1908 Archäologisches aus Jerusalems Umgebung: Das Heilige Land 52 (1908), pp. 187-193.

1909 Archäologisches aus Jerusalems. Gräberfunde: Das Heilige Land 53 (1909), pp. 33-36.

KENYON, K.M

1960 Excavations at Jericho. Volume One. The Tombs Excavated in 1952-1954, London 1960.

1965 Excavations at Jericho. Volume Two. The Tombs Excavated in 1955-1958, London 1965. 
1966 Excavations in Jerusalem, 1965: Palestine Exploration Quarterly 98 (1966), pp. 73-88. KenYon, K.M. - Holland, T.A.

1982 Excavations at Jericho. Volume Four. The Pottery Type Series and Other Finds, London 1982.

LAPP, P.W.

1963 Palestine: known but mostly unknown: Biblical Archaeologist XXVI (1963), pp. 121-134.

1966 The Dhahr Mirzbaneh Tombs. Three Intermediate Bronze Age Cemeteries in Jordan LYON, D.G. (American School of Oriental Research 4), New Haven 1966.

1907 Report of the Director 1906-1907: American Journal of Archaeology Supplement 11 (1907), pp. 42-49.

MiLEVSKI, I. - BEN OR, K.

2007 Jerusalem, Holyland Park: Hadashot Arkheologiyot 119 (2007) (www.hadashotesi.org.i1/report_detail_eng.aspx?id=581\&mag_id=112).

MileVsKi, I. - GREENHUT, Z. - AGHA, N.

2010 Excavations at the Holyland Compound: a Bronze Age cemetery in the Rephaim Valley Western Jerusalem: P. Matthiae - F. Pinnock - L. Nigro - N. Marchetti (eds.), Proceedings of the $6^{\text {th }}$ International Congress on the Archaeology of the Ancient Near East, May, $5^{\text {th }}-10^{\text {th }} 2008$, "Sapienza" - Università di Roma, Wiesbaden 2010, pp. 397415.

NEGBI, O.

1964 Tombs near Manahat South-West of Jerusalem: Israel Exploration Journal 14 (1964), p. 114.

NigRO, L.

1999 Sei corredi tombali del Bronzo Antico IV dalla necropoli di Gerico ai Musei Vaticani: Monumenti Musei e Gallerie Pontificie Bollettino XIX (1999), pp. 5-52.

2003a Tell es-Sultan in the Early Bronze Age IV (2300-2000 BC). Settlement vs Necropolis - A Stratigraphic Periodization: Contributi e Materiali di Archeologia Orientale IX (2003), pp. 121-158.

2003b L'ascia fenestrata e il pugnale venato: due tipologie di armi d'apparato e l'inizio dell'età del Bronzo Medio in Palestina: Bollettino dei Monumenti e Musei e Gallerie Pontificie 23 (2003), pp. 7-42.

2015 Bethlehem in the Bronze and Iron Age. A Summary in the light of recent discoveries by The Palestinian MOTA-DACH: Vicino Oriente XIX (2015), pp. 1-15.

Nigro, L. - MONTANARI, D. - GHAYYADA, M. - YASINE, J.

2015 Khalet al-Jam'a. A Middle Bronze and Iron Age necropolis near Bethlehem (Palestine): Vicino Oriente XIX (2015), pp. 185-218.

Nigro, L. - Montanari, D. - Guari, A. - Tamburrini, M. - Izzo, P. - Ghayyada, M. - Titi, I. YASINE, J.

2017 New archaeological features in Bethlehem (Palestine): the Italian-Palestinian rescue season of 2016: Vicino Oriente XXI (2017), pp. 5-57.

Palumbo, G.

1986 Per un'analisi delle sepolture contratte del Bronzo Antico IV di Gerico: Contributi e Materiali di Archeologia Orientale I (1986), pp. 287-306.

1987 "Egalitarian" or "Stratified" Society? Some Notes on Mortuary Practices and Social Structures at Jericho in EB IV: Bulletin of American School of Oriental Research 267 (1987), pp. 43-59. 
PrAG, K.

1995 The Intermediate Early Bronze-Middle Bronze Age Cemetery on the Mount of Olives: I. ESHEL - K. PRAG (eds.), Excavations by K.M. Kenyon in Jerusalem 1961-1967. Volume IV. The Iron Age Cave Deposits on the South-east Hill and Isolated Burials and Cemeteries Elsewhere (British School Academy Monographs in Archaeology 6), Hertford 1995, pp. 221-241.

2000 Bethlehem: A Site Assessment: Palestine Exploration Quarterly 132 (2000), pp. 169-181.

2013 Bethlehem: D.M. MAster (ed.), The Oxford Encyclopedia of the Bible and Archaeology, Volume I, Oxford 2013, pp. 104-110.

PRITCHARD, J.B.

1963 The Bronze Age Cemetery at Gibeon, Philadelphia 1963.

RAHMANI, L.Y.

1981 Ancient Jerusalem's Funerary Customs and Tombs: Part Two: Biblical Archaeologist 44/4 (1981), pp. 229-235.

SA'AD, Y.

1964 A Bronze Age Tomb Group from Hablet el Amud, Silwan Village Lands: Annual of the SALLER, S.J. Department of Antiquities of Jordan 8 (1964), pp.77-80.

1962 Jerusalem and its surroundings in the Bronze Age: Liber Annuus XII (1962), pp. 147-176.

1963 Archaeological Activity in the Holy Land 1962/3: Liber Annuus XIII (1963), pp. 323-328.

1964 Recent Archaeological work in Palestine: Liber Annuus XIV (1964), pp. 272-292.

SELIGMAN, J.

1993 Jerusalem, Pisgat Ze'ev (East A): Exploration and Survey in Israel 10 (1993), pp. 52-54.

1995 Shaft Tombs of the Early Bronze Age IV at Pisgat Ze'ev (Ras Abu-Ma'aruf) - Jerusalem: 'Atiqot 27 (1995), pp. 191-197.

SHAUB, R.T. - RAST, W.E.

1989 Bâb edh-Dhrâ': Excavations in the Cemetery directed by Paul W. Lapp (1965-67) SMITH, R.B. (Reports of the Expedition to the Dead Sea Plain, Jordan, Volume I), Winona Lake 1989.

1962 Excavations in the Cemetery at Khirbet Küfin, Palestine (Colt Archaeological Institute. TUFNELL, O Monograph Series I), London 1962

$1958 \quad$ Lachish IV (Tell ed-Duweir) The Bronze Age, Oxford 1958.

VINCENT, J.H.

1909 Chronique - Bethléem: Revue Biblique 6 (1909), pp. 107-127.

1914 Chronique - Un hypogée Cananèen a Béthanie: Revue Biblique 11 (1914), pp. 438-441.

WEKSLER-BDOLAH, D

2017 Intermediate and Middle Bronze Age Burial Cave 900 in Nahal Refa'im, Jerusalem: 'Atiqot 88 (2017), pp. 17-32.

WILSON, C. - WARREN, C.

1871 The Recovery of Jerusalem, London 1871.

WRIGHT, G.E.

1938 The Chronology of Palestinian Pottery in Middle Bronze I: Bulletin of American School of Oriental Research 71 (1938), pp. 27-34.

ZeHAVI, A.

1993 Jerusalem, Manahat: Exploration and Survey in Israel 12 (1993), pp. 66-67.

ZELINGER, Y. - GOLAN, A.

2005 Rock-cut Shaft Tombs from the Intermediate Bronze Age near the Holyland Hotel, Jerusalem: 'Atiqot 49 (2005), pp. 1-6. 


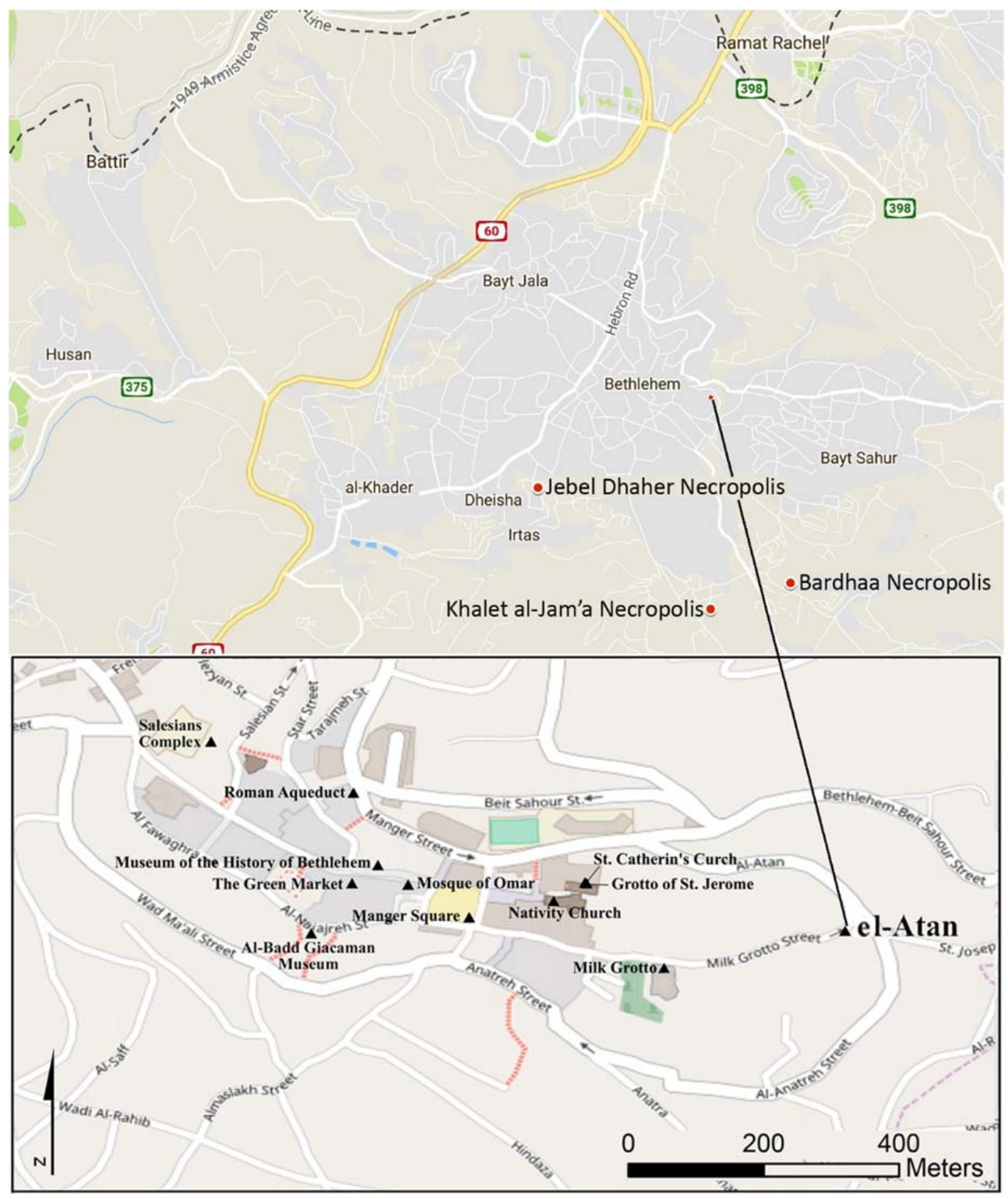

Fig. 1 - Map of the area of Bethlehem with cemeteries cited in the text (up), and a detail of the city centre and the position of el-Atan Tomb (down). 

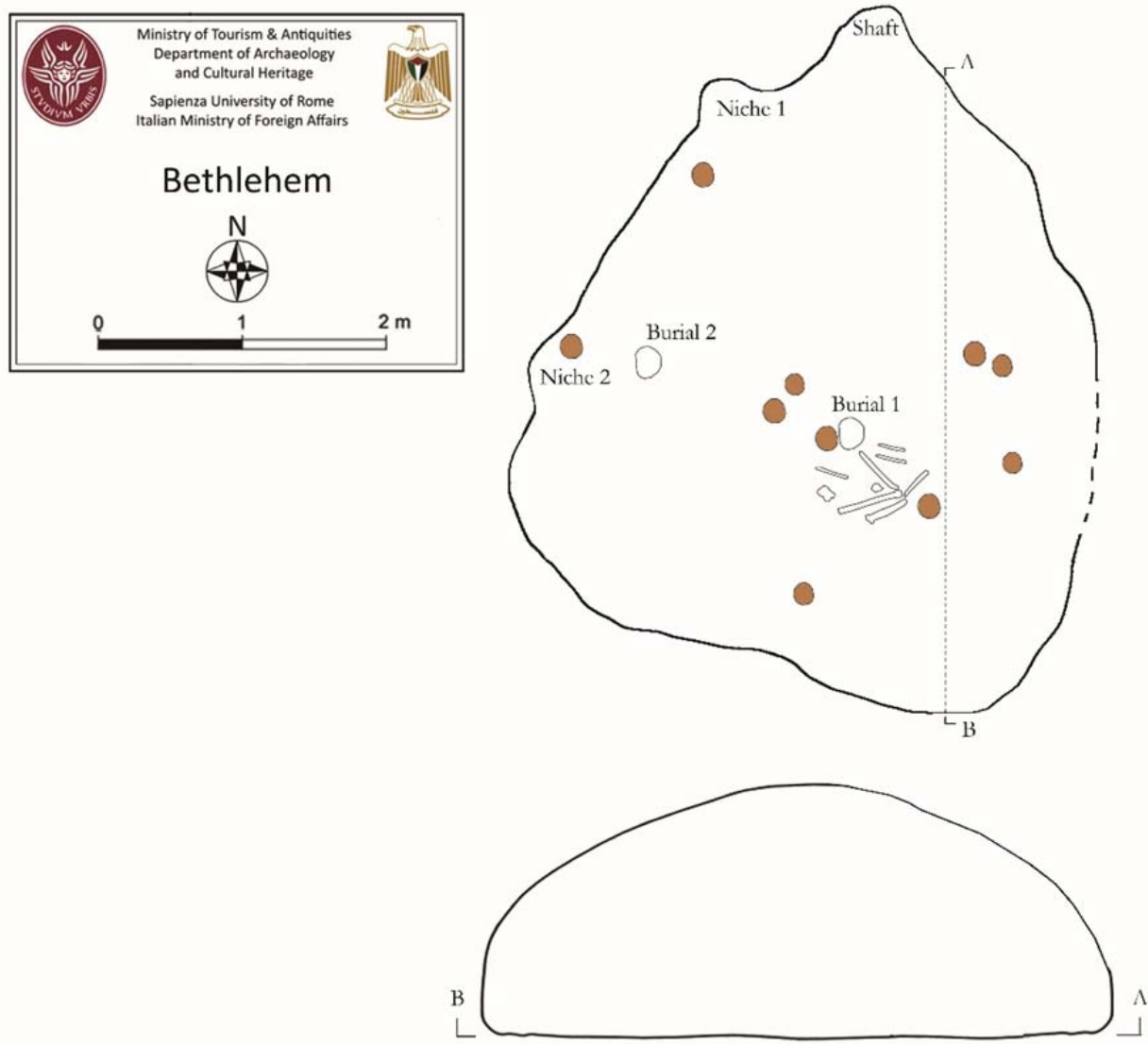

Fig. 2 - Plan of el-Atan Tomb.

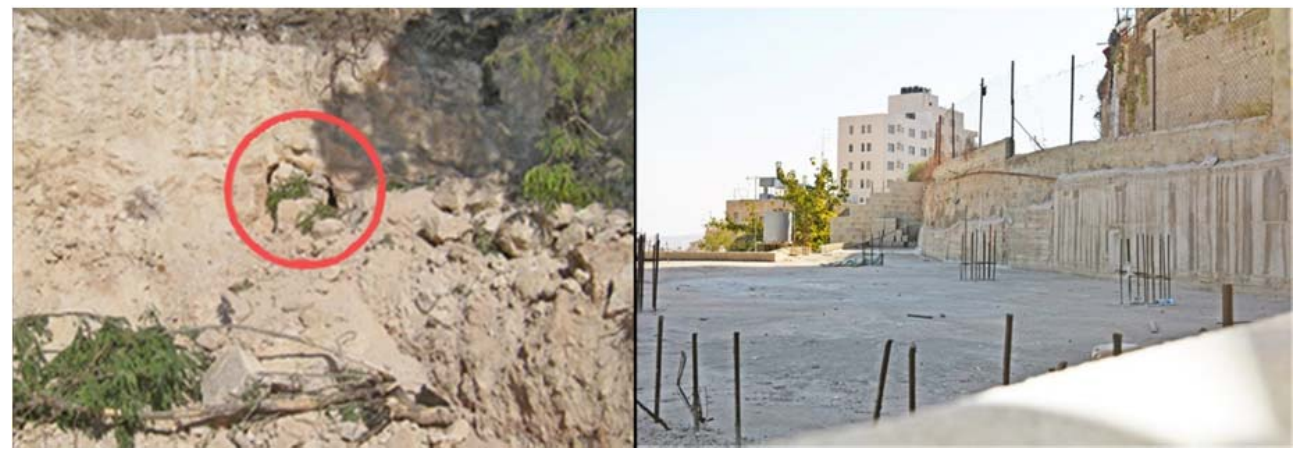

Fig. 3 - On the left, the entrance to el-Atan Tomb at the moment of discovery in June 2009; on the right, the same place under construction in November 2016. 
Fig. 4 - Entrance to the el-Atan Tomb at the moment of discovery on June 2009.
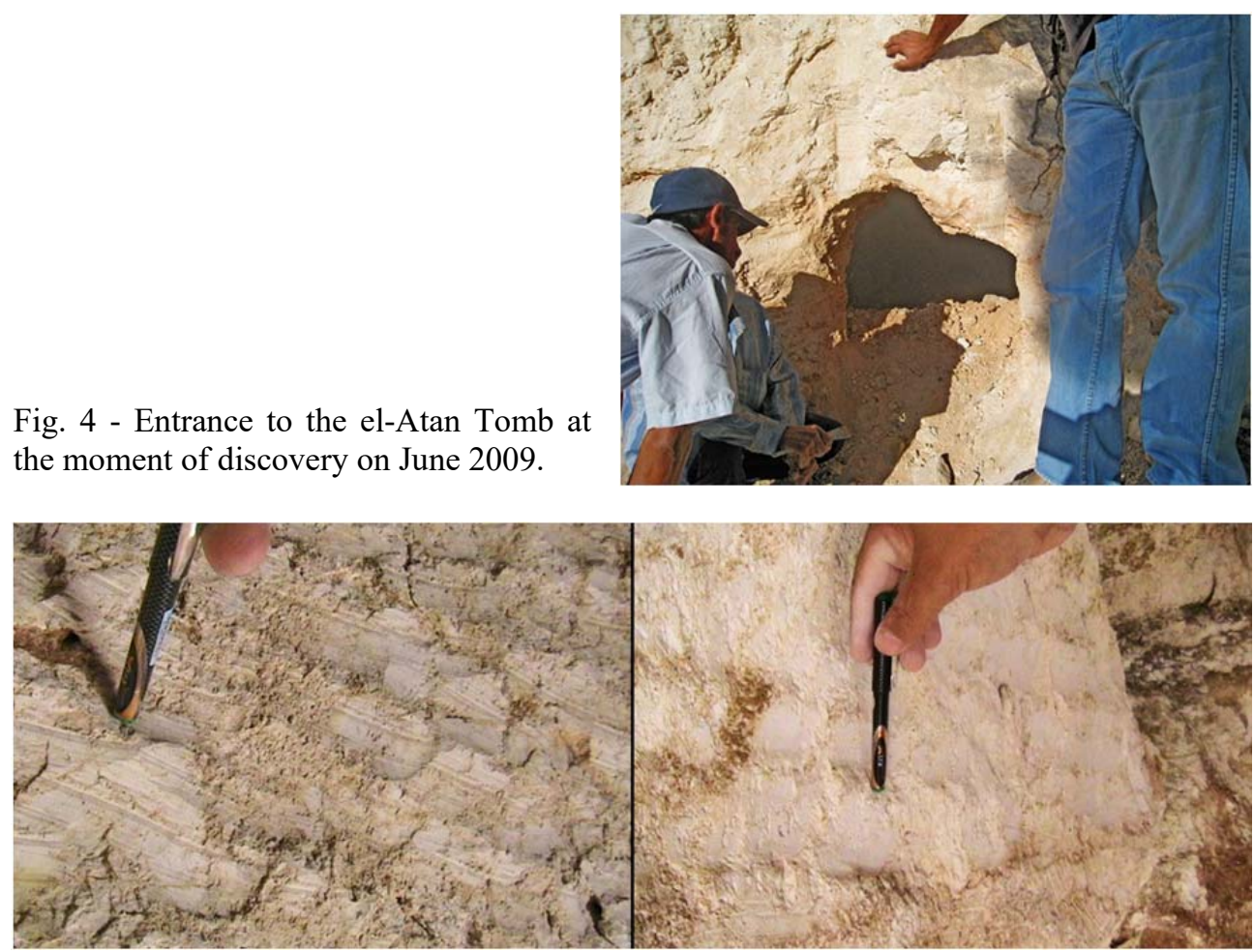

Fig. 5 - Tool marks in southern and western walls of the chamber of el-Atan Tomb.

Fig. 6 - A detail of Burial 1 in the el-Atan Tomb during excavations on June 2009.

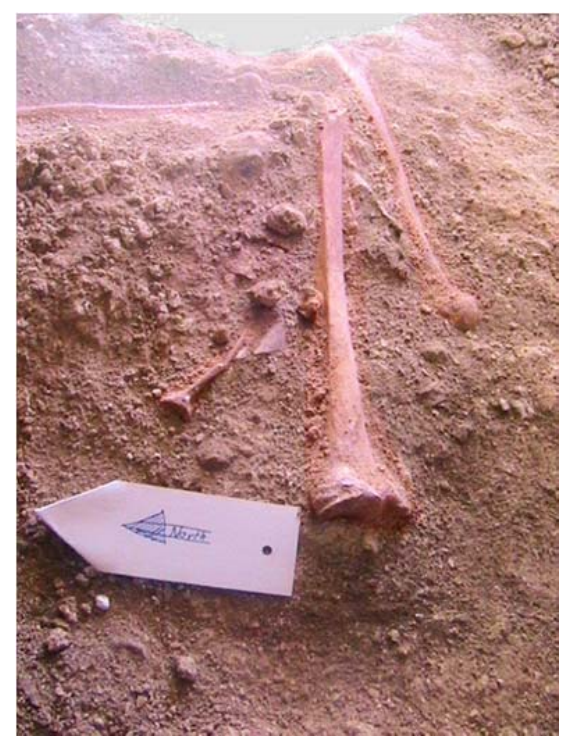




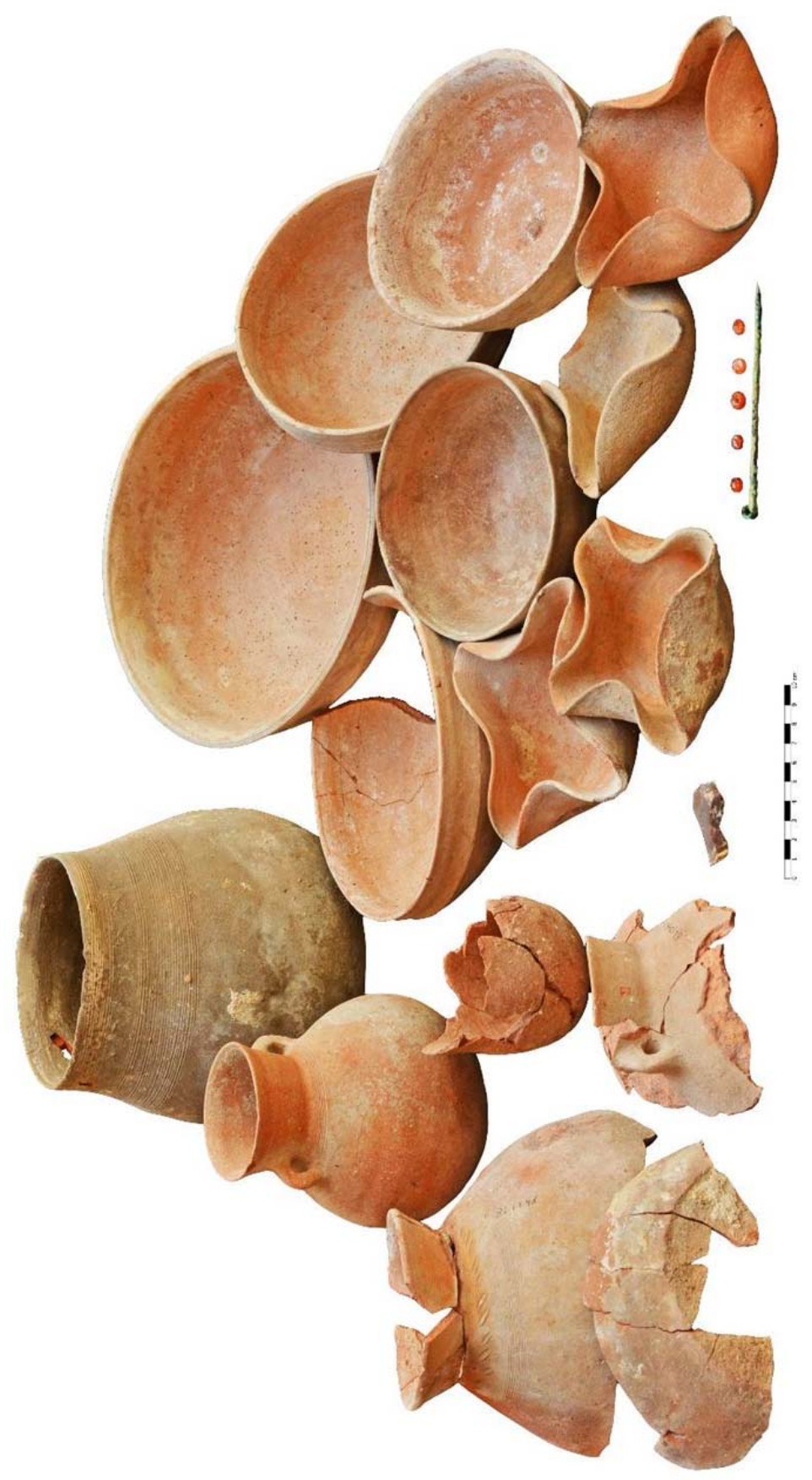

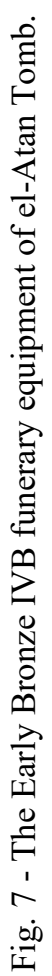




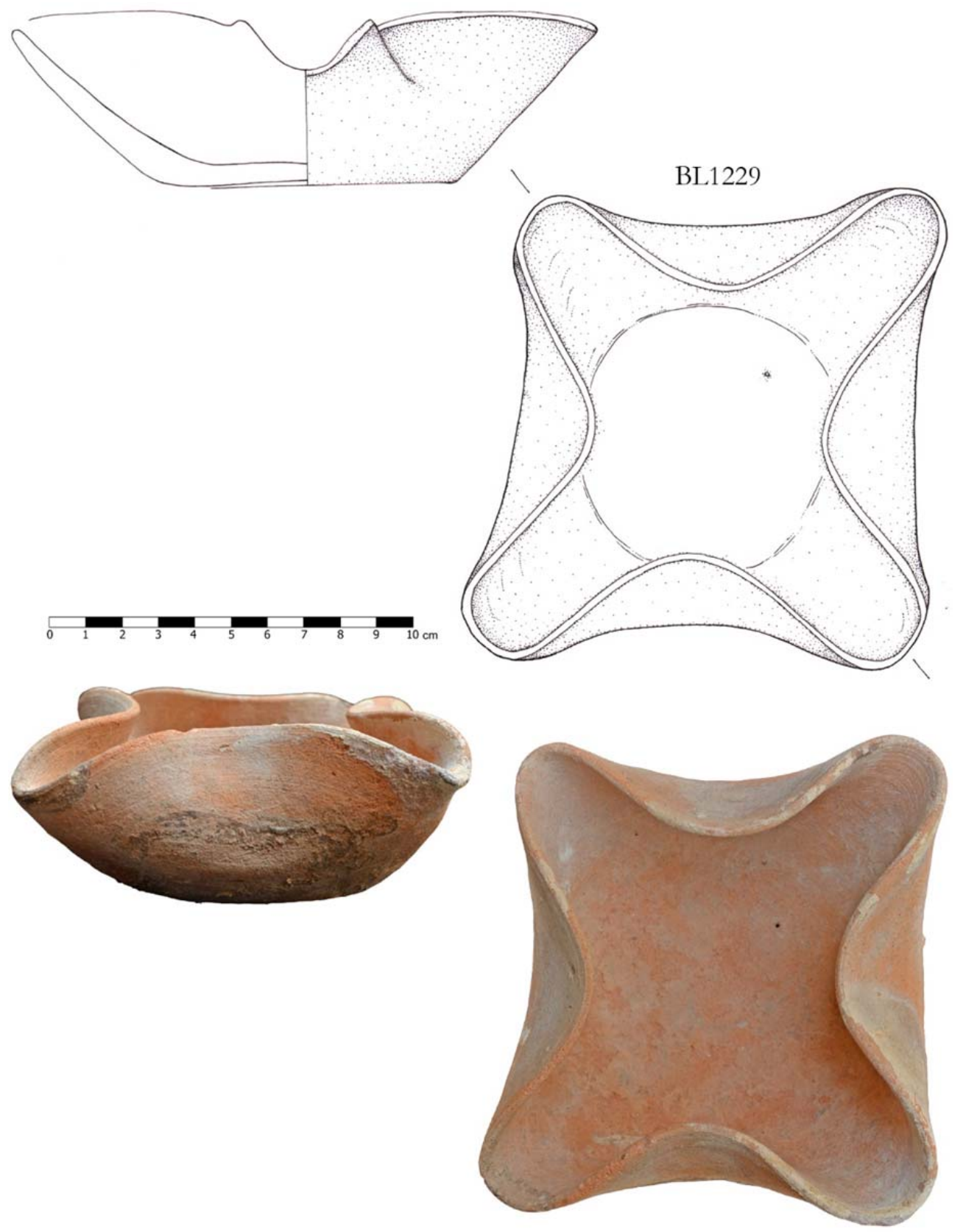

Fig. 8 - The four-spouted lamp BL1229 of el-Atan Tomb (ratio 1:2). 


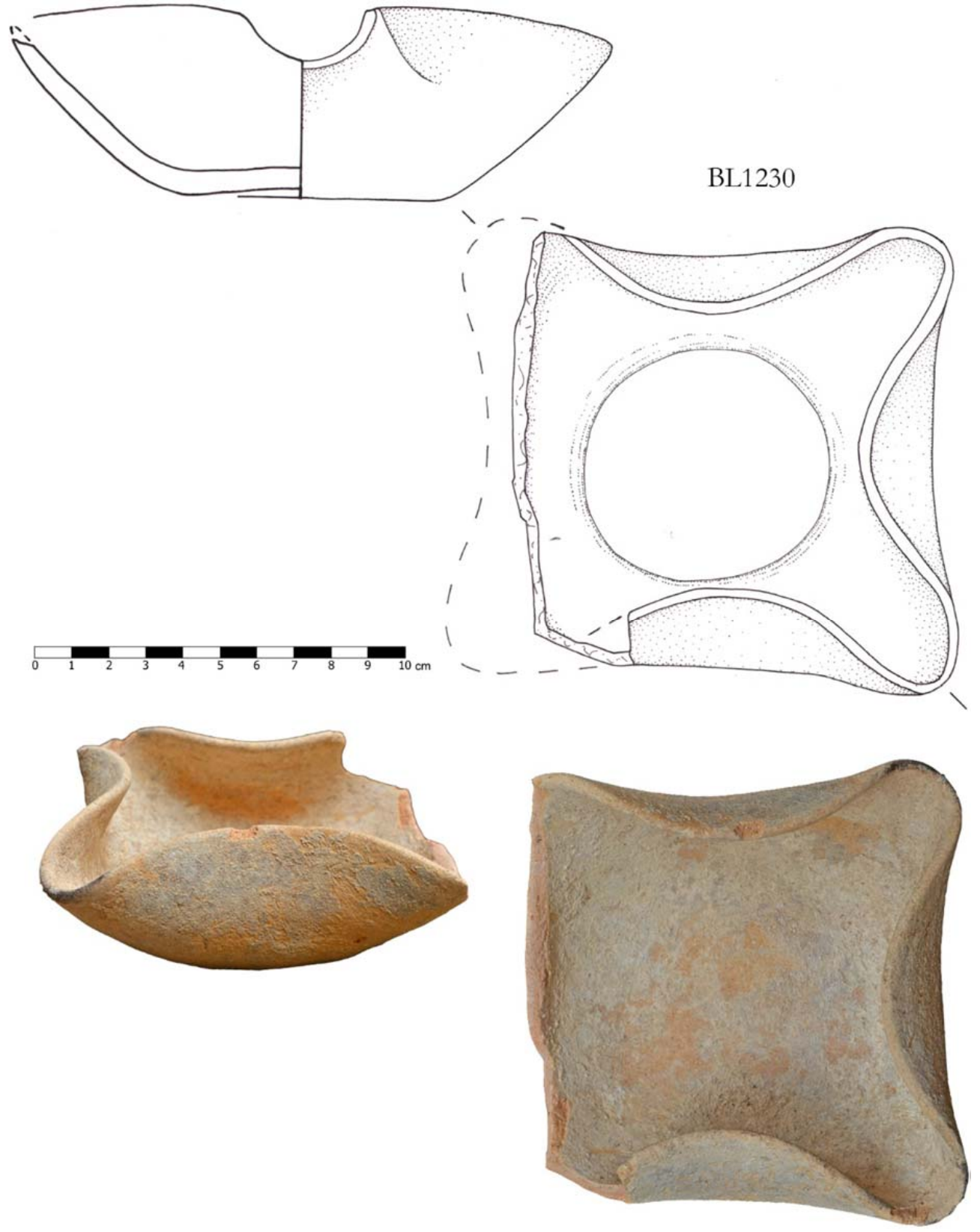

Fig. 9 - The four-spouted lamp BL1230 of el-Atan Tomb (ratio 1:2). 


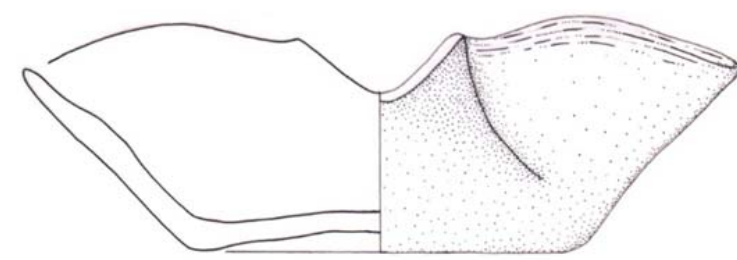

BL1231
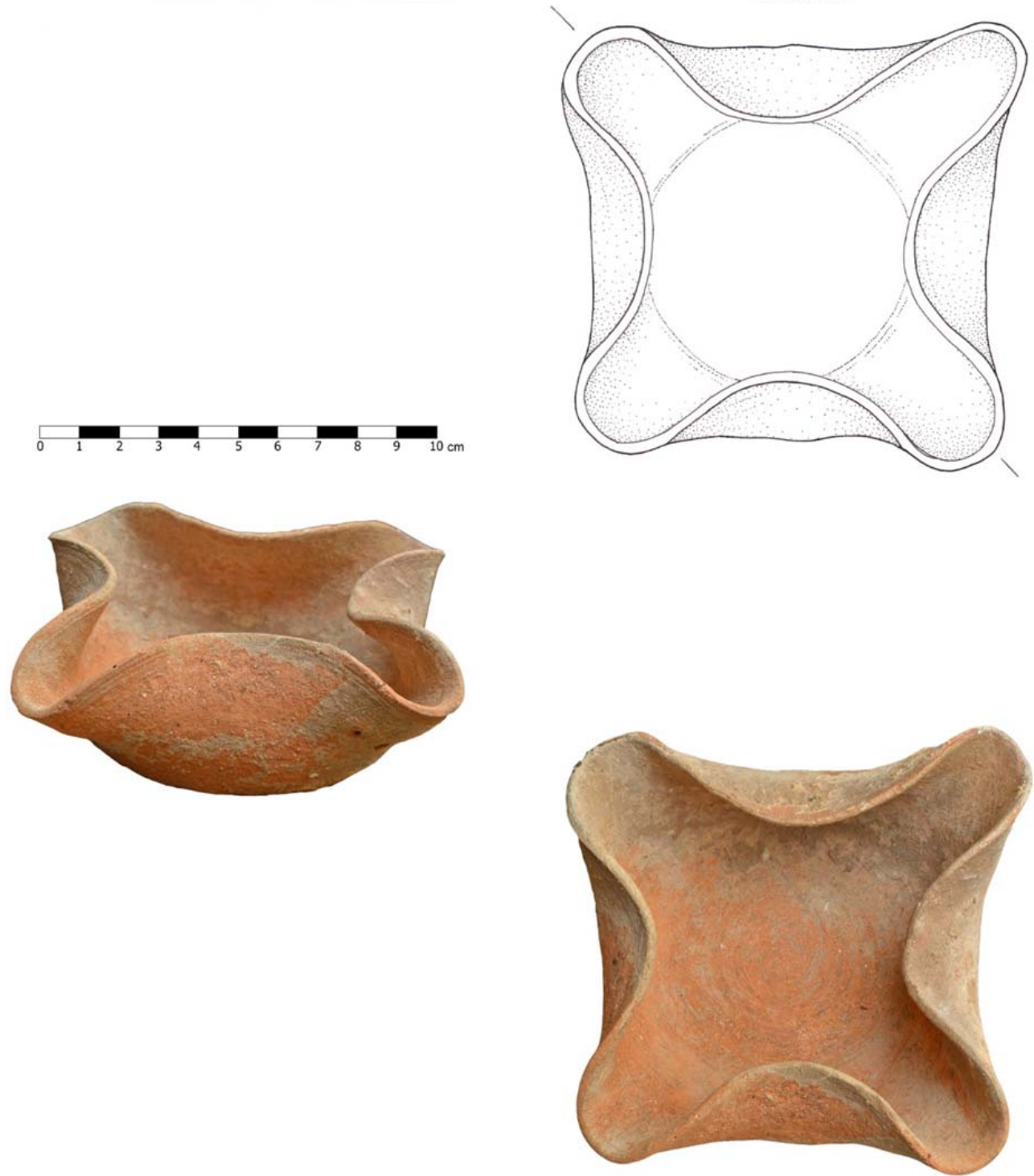

Fig. 10 - The four-spouted lamp BL1231 of el-Atan Tomb (ratio 1:2). 


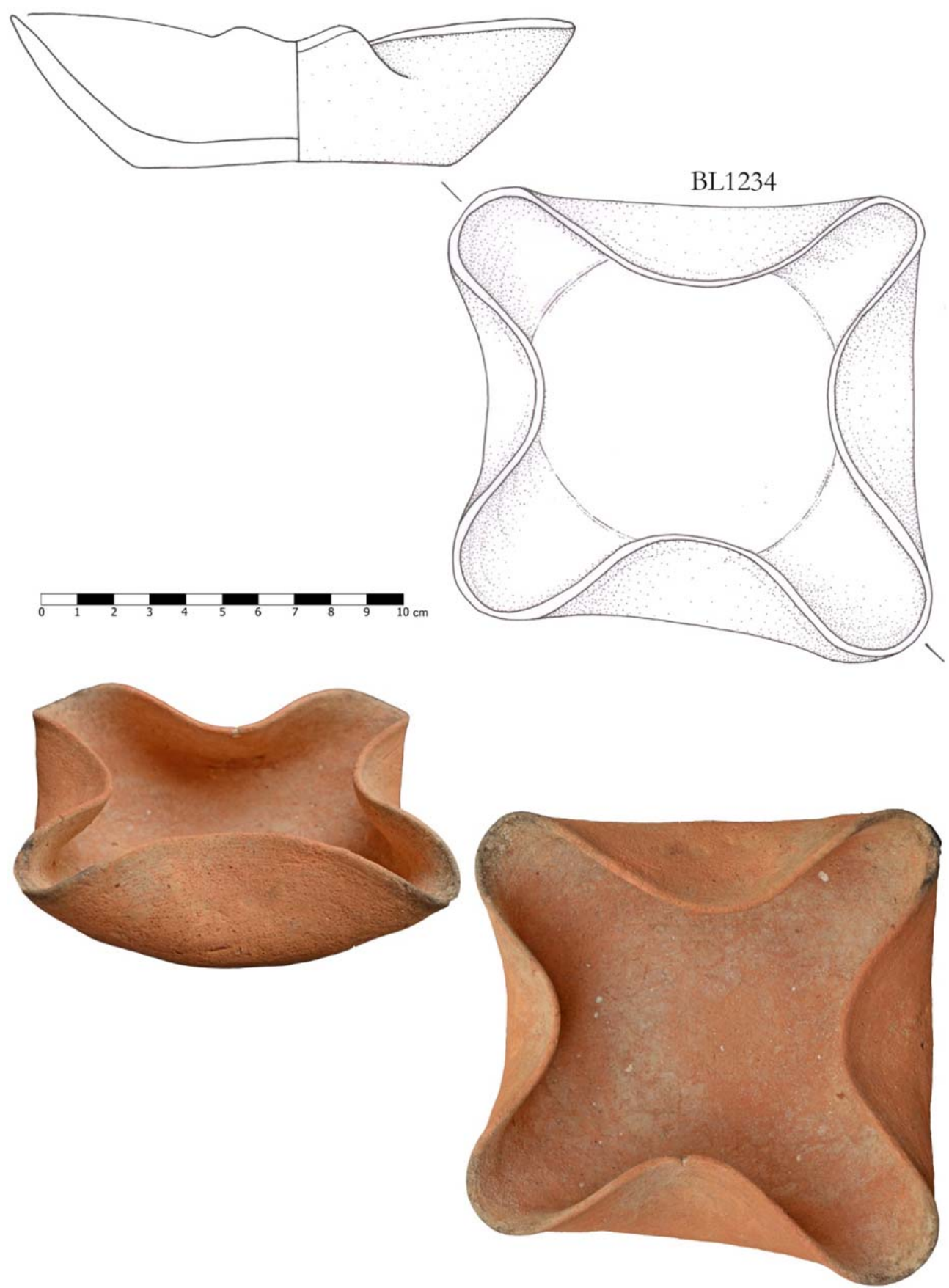

Fig. 11 - The four-spouted lamp BL1234 of el-Atan Tomb (ratio 1:2). 

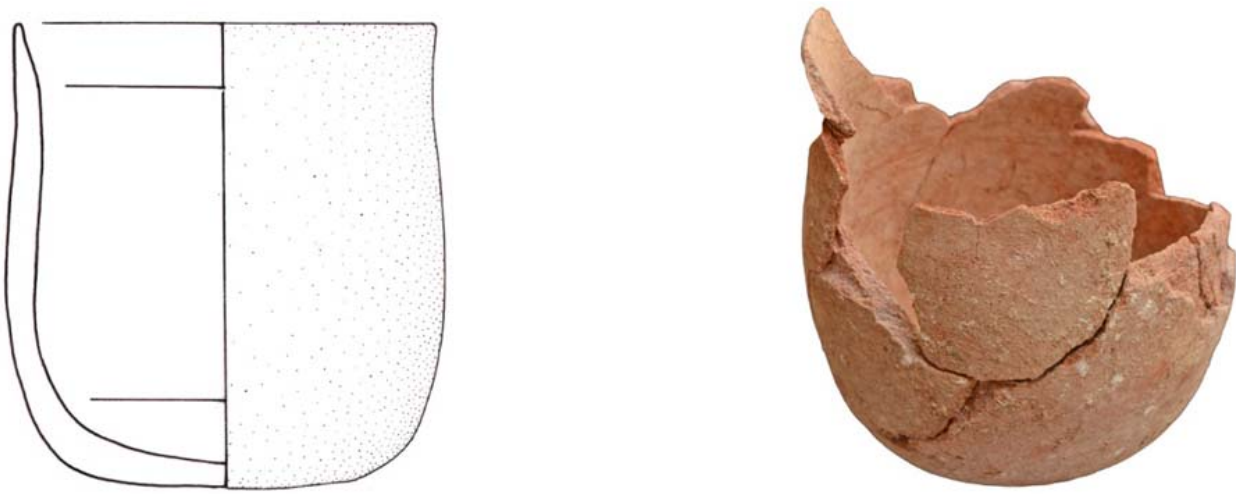

BL1244
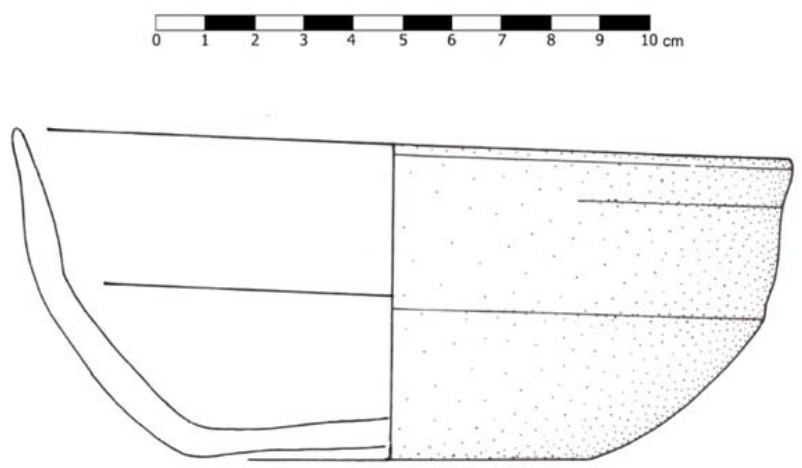

BL1235

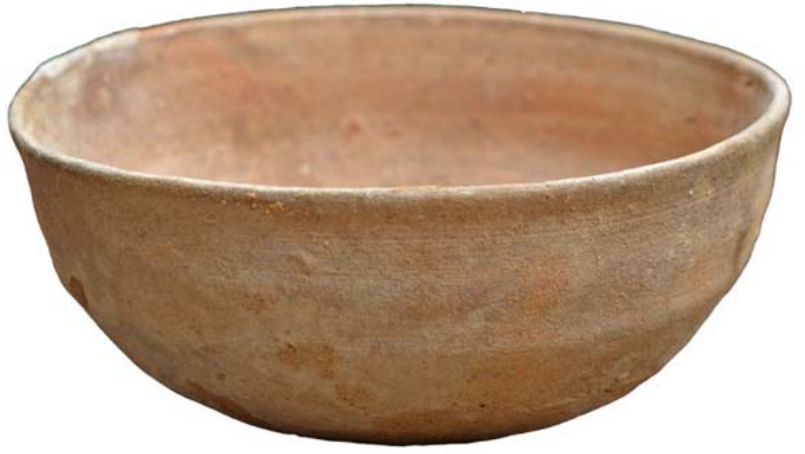

Fig. 12 - The beaker BL1244 and the carinated bowl BL1235 of el-Atan Tomb (ratio 1:2). 


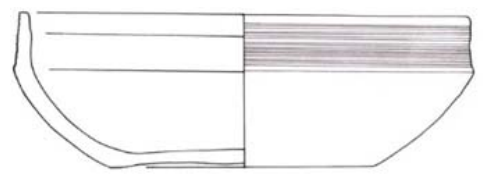

BL1228
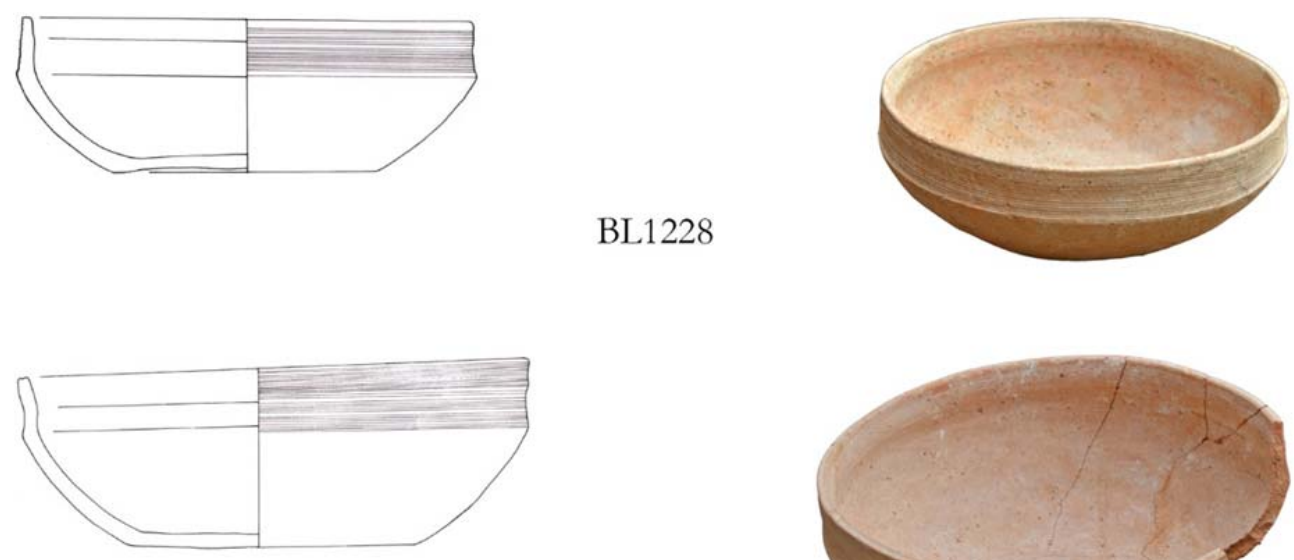

BL1232
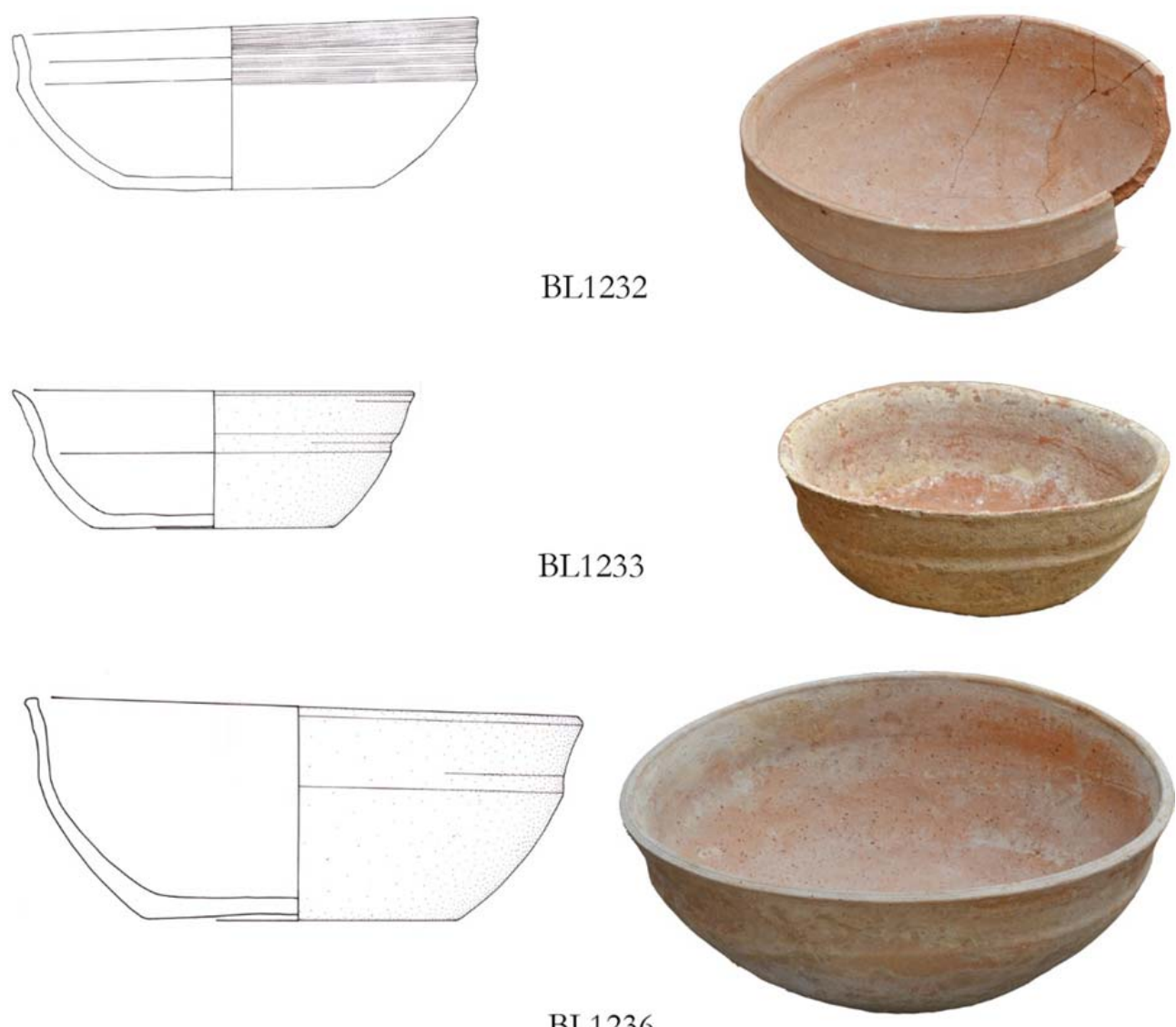

BL1236

BL1233

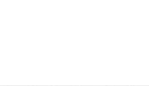

Fig. 13 - Carinated bowls of el-Atan Tomb: BL1228 and BL1232 with grooved decoration under the rim; BL1233 and BL1236 carinated bowls (ratio 1:4). 


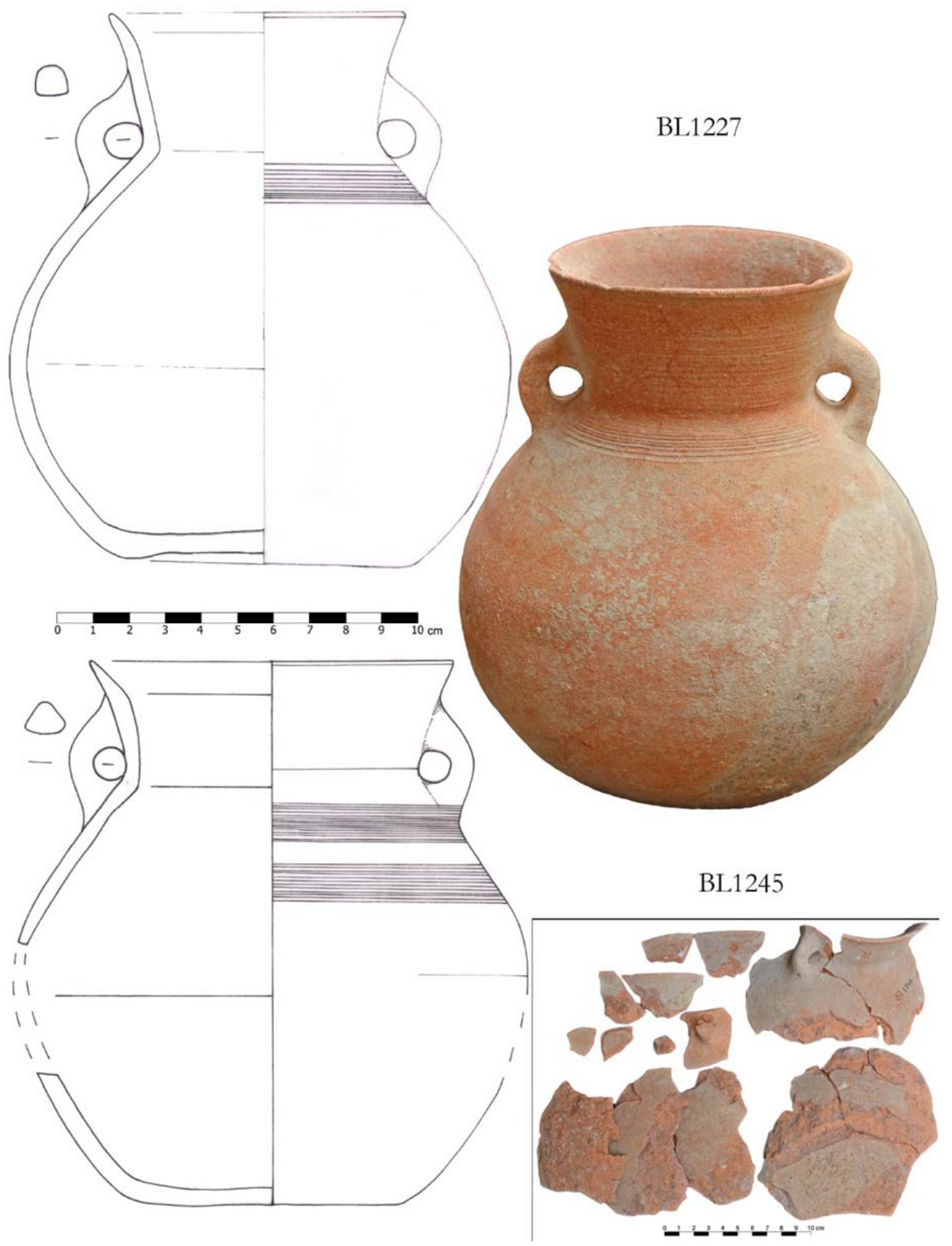

Fig. 14 - Amphoriskoi BL1227 and BL1245 of el-Atan Tomb (ratio 1:2). 

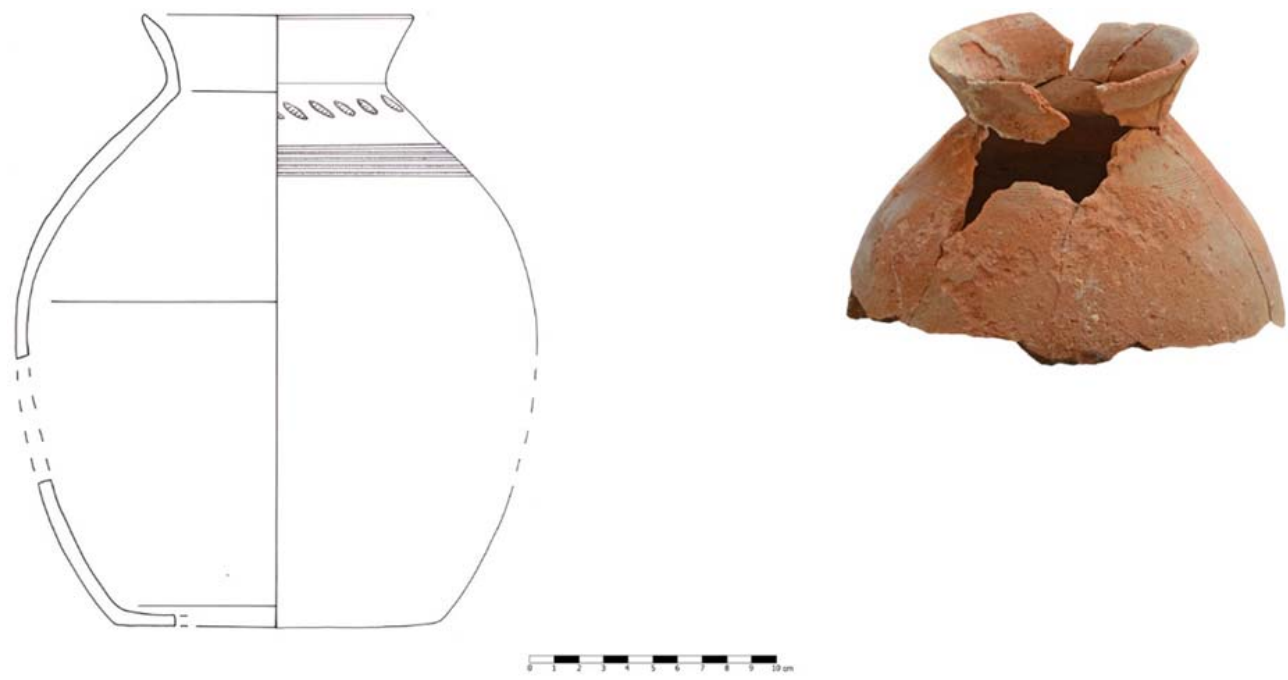

BL1246

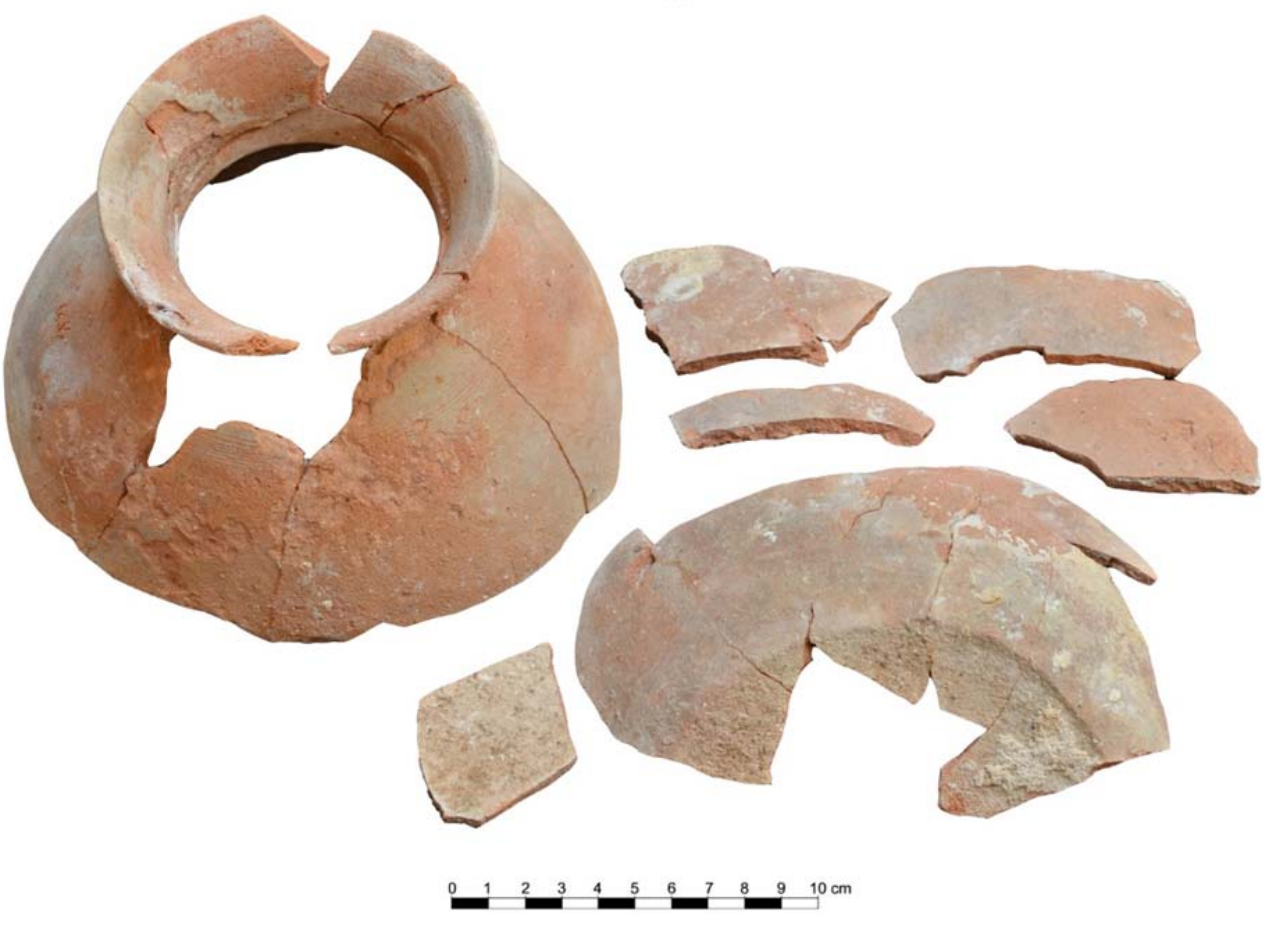

Fig. 15 - Jar BL1246 with combed decoration of el-Atan Tomb (ratio 1:4). 


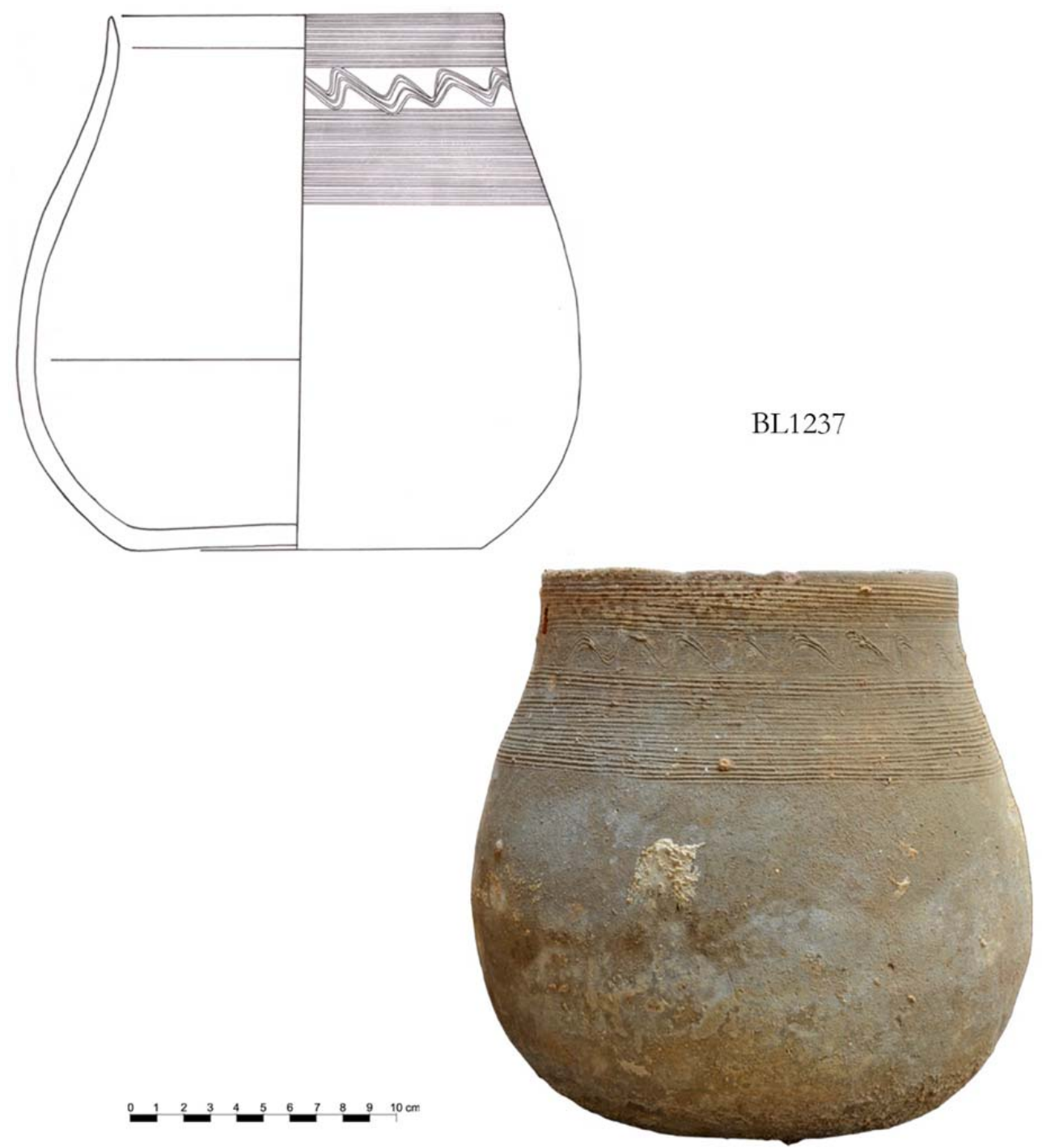

Fig. 16 - The 'oversize cup' BL1237 with band and wave combed decoration of el-Atan Tomb (ratio 1:3). 

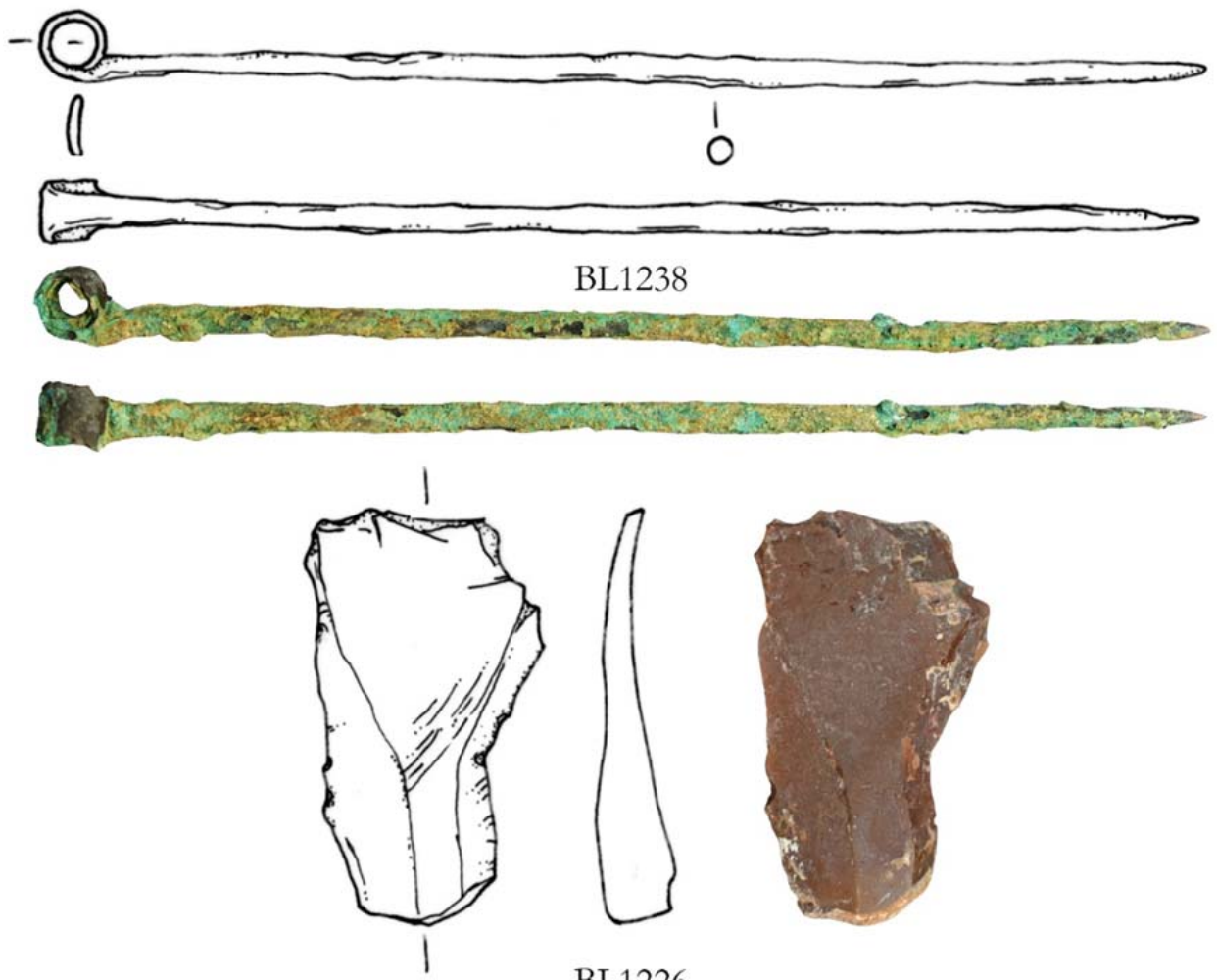

BL1226

$\infty_{1}^{1} 00$

BL1225

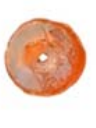

(1)

BL1239
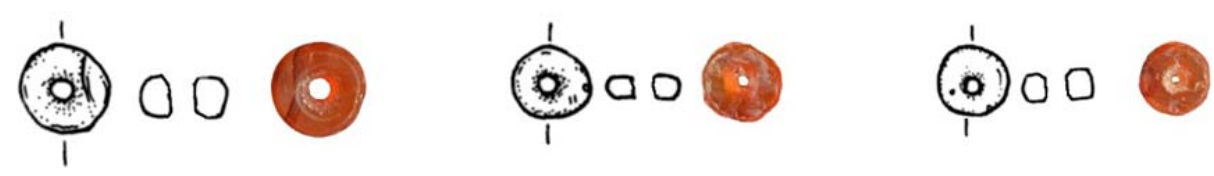

BL1240

BL1241

BL1242

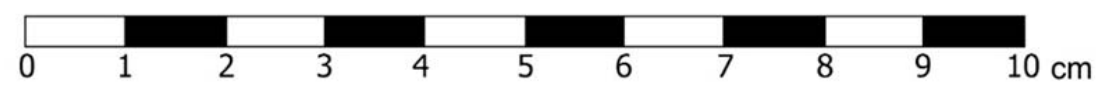

Fig. 17 - Rolled pin BL1238, flint scraper BL1226 and carnelian beads of el-Atan Tomb (ratio 1:1). 


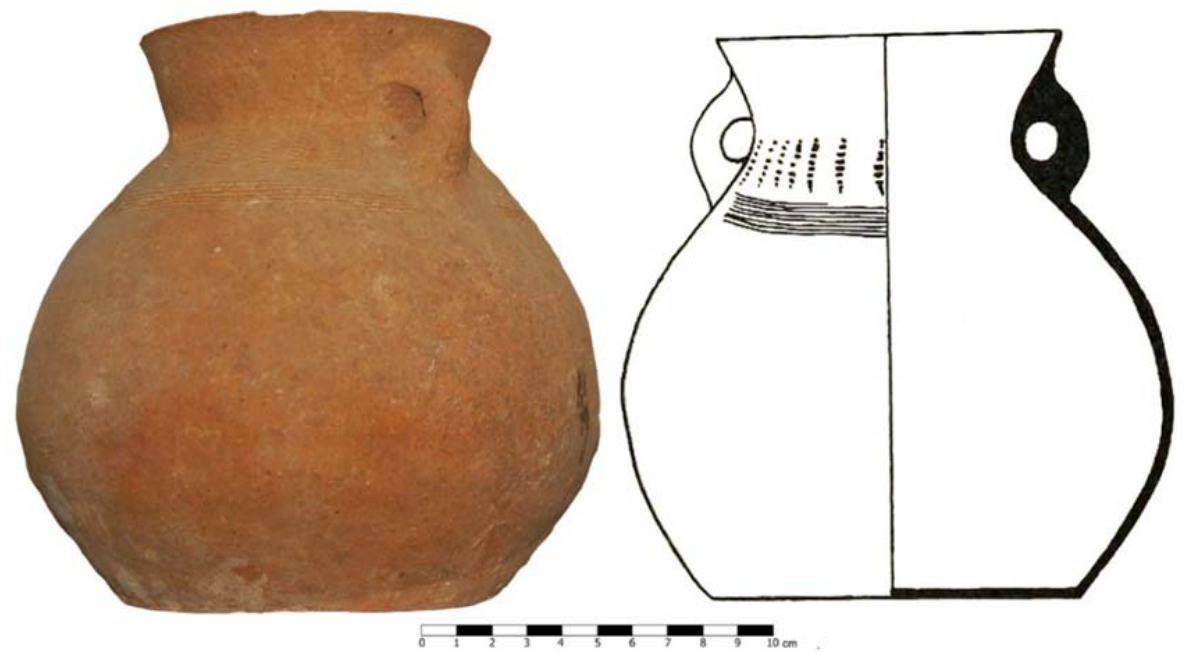

Fig. 18 - Early Bronze IV amphoriskos from Battir in the Flagellation Museum (after Saller 1962, fig. 1:10).

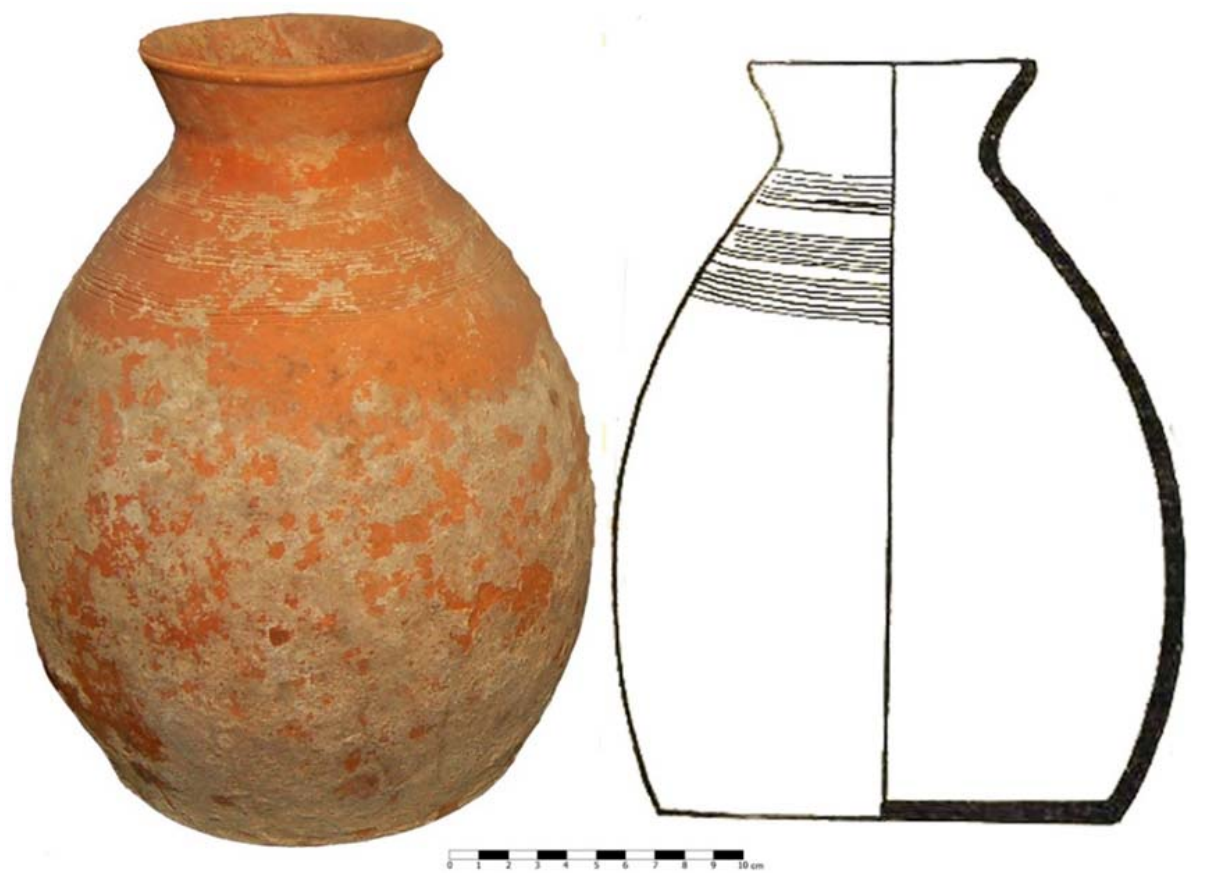

Fig. 19 - Early Bronze IV jar with combed decoration in the Flagellation Museum (after Saller 1962, fig. 2:16). 


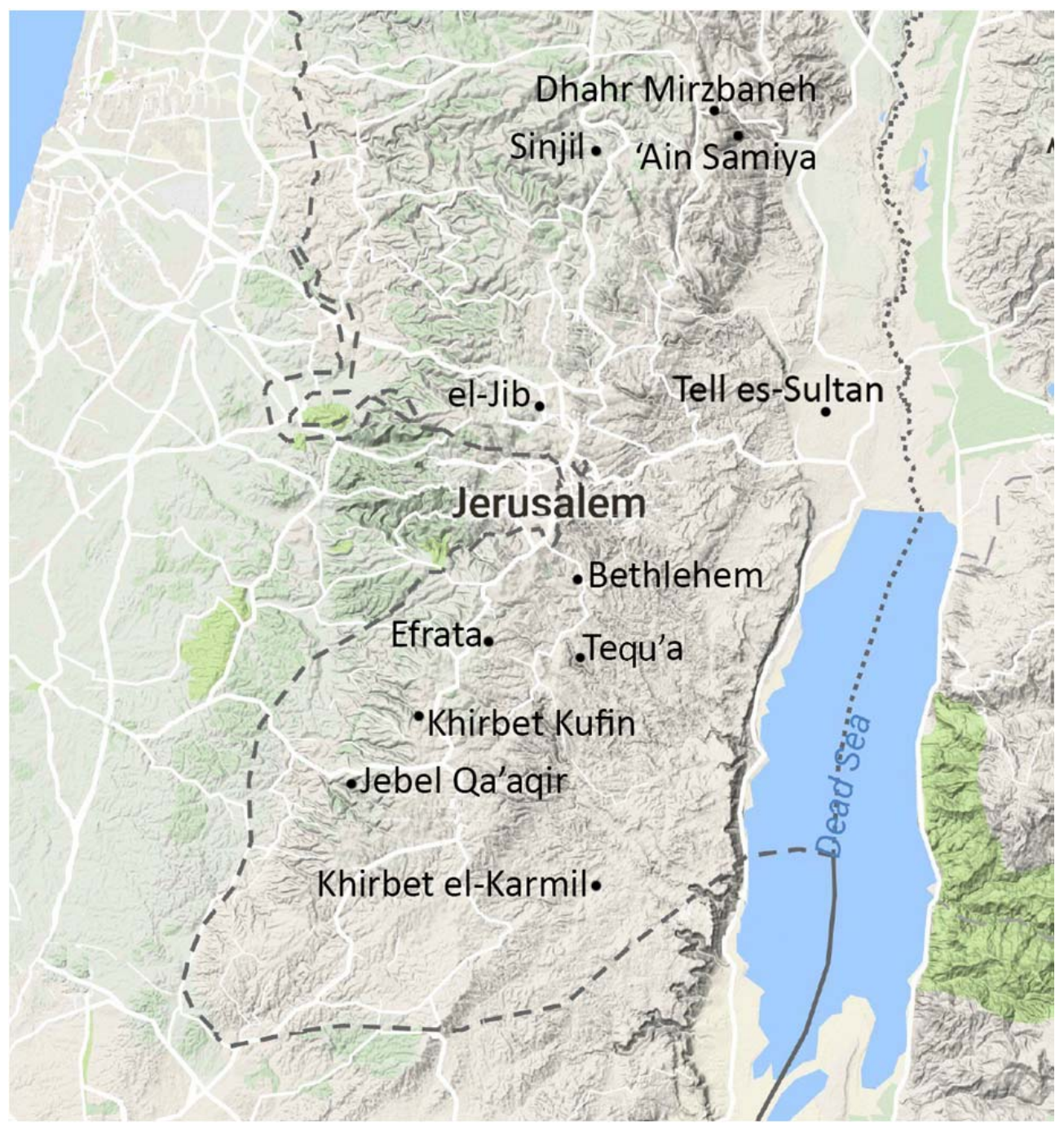

Fig. 20 - Map of Central Hills and Judean Hills with cemeteries quoted in the text. 

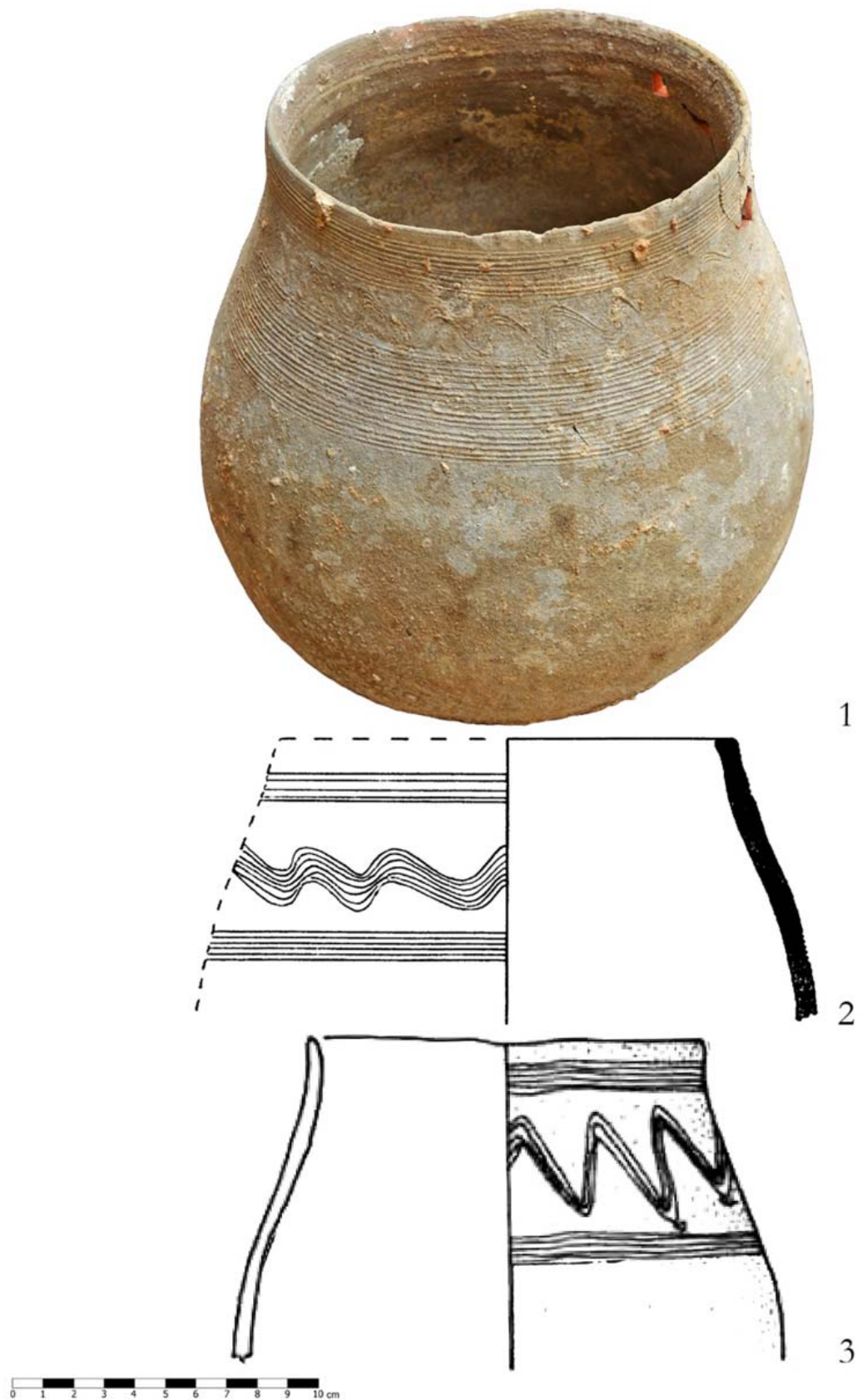

Fig. 21 - Biconical jar of el-Atan (1); (2) from Wadi ed- Daliyeh (after Dever 1974, pl. 13:3); (3) from Tell es-Sultan (after Nigro 2003, fig. 20:5). 


\section{ARABIC ABSTRACT}

\section{قبر العطن}

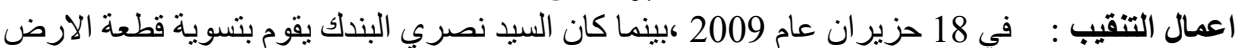

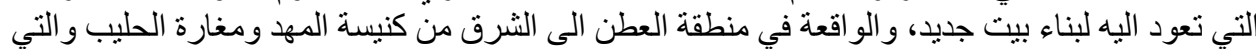

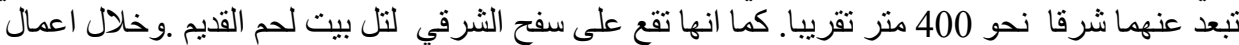
التجريف فقد ضربت الاليات بالجدار الثرقي من القبر عاملة فتحة فيه ،ولحسن الحظ ان القبر بقي سليما لم

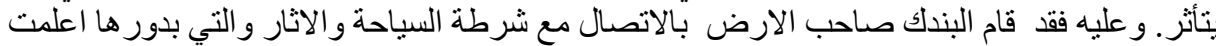

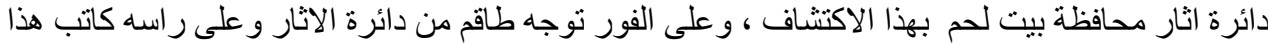

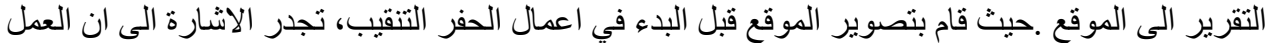

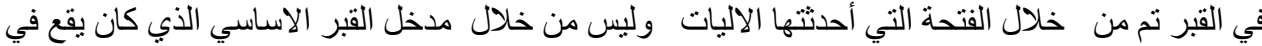

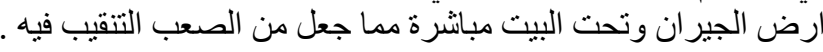
وصف القبر :

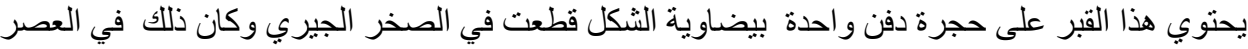

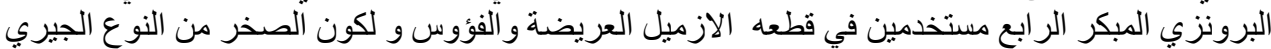

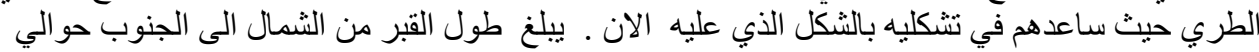

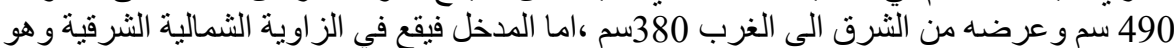

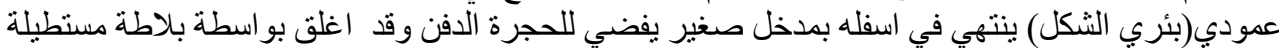

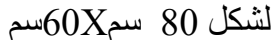

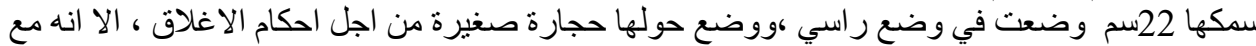

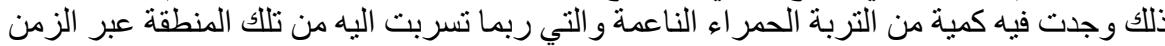

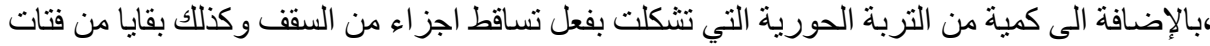

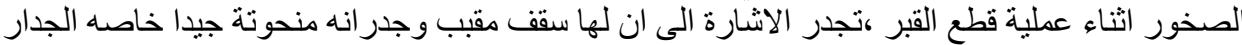

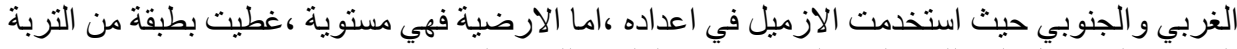

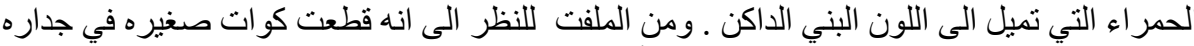

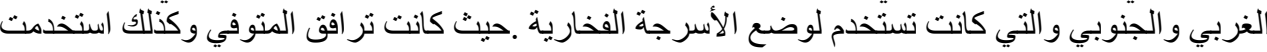
الثناء عملية الدفن للإنارة.

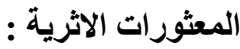

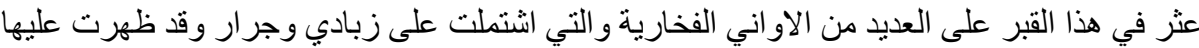

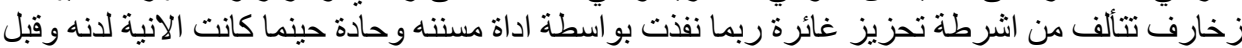

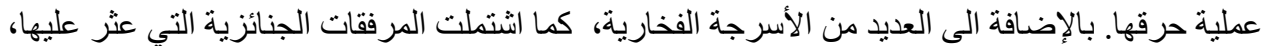

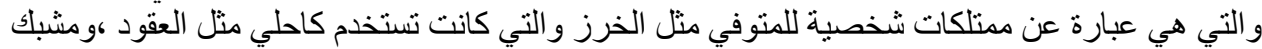

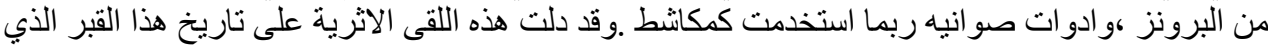

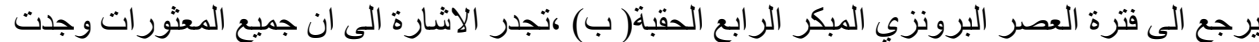

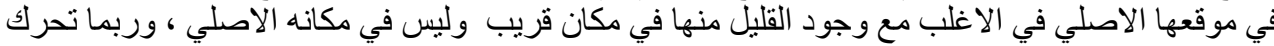

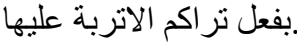

تجدر الاشارة الى انه تم العثور على على بقايا لعظام شابة كانت في وضع الانتثناء و وعلى جانبها الأيمن ووجها

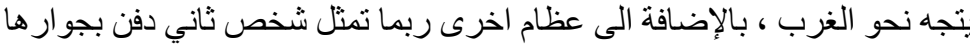

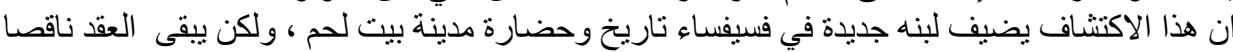

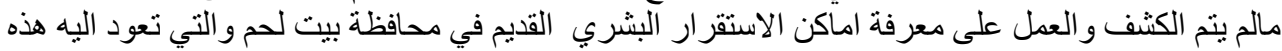


المدافن سو اء في منطقة العطن او منطقة خلة الجامع وجبل ظاهر او خلايل اللوز و هذه المنطقة تعتبر بكر

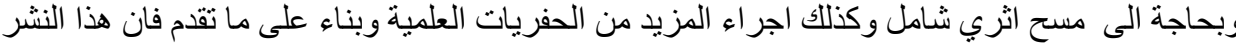

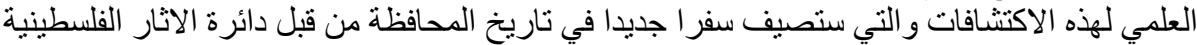

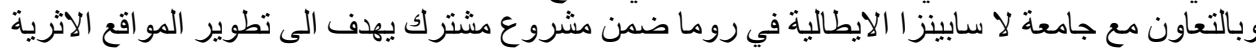

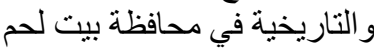
حمح غياظة مدير دائرة محافظة بيت لحم 